\title{
The Growth Arrest-Specific Gene Product Gas6 Promotes the Survival of Human Oligodendrocytes via a Phosphatidylinositol 3-Kinase-Dependent Pathway
}

\author{
Sai Latha Shankar, ${ }^{1}$ Kathleen 0'Guin, ${ }^{1}$ Michael Cammer, ${ }^{2}$ F. Arthur McMorris, ${ }^{3}$ Trevor N. Stitt, ${ }^{4}$ Ross S. Basch, ${ }^{5}$ \\ Brian Varnum, ${ }^{6}$ and Bridget Shafit-Zagardo ${ }^{1}$ \\ ${ }^{1}$ Department of Pathology and ${ }^{2}$ Analytical Imaging Facility, Albert Einstein College of Medicine, Bronx, New York 10461, ${ }^{3}$ The Wistar Institute, \\ Philadelphia, Pennsylvania 19104, ${ }^{4}$ Regeneron Pharmaceuticals, Tarrytown, New York 10591, ${ }^{5}$ Department of Pathology, New York University School of \\ Medicine, New York, New York 10016, and ${ }^{6}$ Amgen Corporation, Thousand Oaks, California 91320
}

Microarray analysis revealed that transcripts for the Axl and Mer receptor tyrosine kinases are expressed at high levels in $04^{+}{ }_{-}$ immunopanned oligodendrocytes isolated from second trimester human fetal spinal cord. In humans the sole known ligand for the $\mathrm{Axl} / \mathrm{Rse} / \mathrm{Mer}$ kinases is growth arrest-specific gene 6 (Gas6), which in the CNS is secreted by neurons and endothelial cells. We hypothesized that Gas6 is a survival factor for oligodendrocytes and receptor activation signals downstream to the phosphatidylinositol 3 (PI3)-kinase/Akt pathway to increase cell survival in the absence of cell proliferation. To test this hypothesis, we grew enriched human oligodendrocytes for $6 \mathrm{~d}$ on a monolayer of NIH3T3 cells stably expressing Gas6. CNP ${ }^{+}$oligodendrocytes on Gas6-secreting 3T3 cells had more primary processes and arborizations than those plated solely on 3T3 cells. Also, a twofold increase in $\mathrm{CNP}^{+}$and $\mathrm{MBP}^{+}$oligodendrocytes was observed when they were plated on the Gas6-secreting cells. The effect was abolished in the presence of Axl-Fc but remained unchanged in the presence of the irrelevant receptor fusion molecule TrkA-Fc. A significant decrease in $\mathrm{CNP}^{+} / \mathrm{TUNEL}^{+}$oligodendro- $^{-}$ cytes was observed when recombinant human Gas6 (rhGas6) was administered to oligodendrocytes plated on poly-L-lysine, supporting a role for Gas6 signaling in oligodendrocyte survival during a period of active myelination in human fetal spinal cord development. PI3-kinase inhibitors blocked the anti-apoptotic effect of rhGas6, whereas a MEK/ERK inhibitor had no effect. Thus Gas6 sustains human fetal oligodendrocyte viability by receptor activation and downstream signaling via the PI3-kinase/Akt pathway.

Key words: Gas6; oligodendrocytes; human spinal cord; apoptosis; tyrosine kinase receptors; Axl/Rse/Mer

\section{Introduction}

The signaling pathways and molecular events required for human oligodendrocyte survival and maturation have not been elucidated fully. Cultured human oligodendrocytes exhibit poor viability relative to rat oligodendrocytes, which survive in culture for $3 \mathrm{~d}$ before undergoing programmed cell death (Barres et al., 1992; Trapp et al., 1997). Further, studies on oligodendrocyte development in rodents have shown the presence of an oligodendrocyte type 2 astrocyte bipotential progenitor cell that yields oligodendrocytes (Raff et al., 1983), but it is questionable as to whether this progenitor cell exists in human oligodendrocyte development. To identify growth factors deemed important for the survival, differentiation, and/or maturation of human oligodendrocytes, we initiated cDNA microarray analysis of $\mathrm{O}^{+}{ }^{+}$ immunopanned oligodendrocytes from second trimester human fetal spinal cord, a time of active ongoing myelination. Among the novel cDNAs that were identified were members of the re-

Received Nov. 22, 2002; revised Feb. 26, 2003; accepted Feb. 28, 2003.

This work was supported by National Institutes of Health Grant R01NS38102 and National Multiple Sclerosis Society Grant RG 3020-A-1 (B.S.-Z). We thank Dr. Celia F. Brosnan, Albert Einstein College of Medicine, for helpful comments on this manuscript and Dr. Brad Poulos, Einstein Human Fetal Tissue Repository, for material.

Correspondence should be addressed to Dr. Bridget Shafit-Zagardo, Department of Pathology, Forcheimmer 5165, Albert Einstein College of Medicine, 1300 Morris Park Avenue, Bronx, NY 10461. E-mail: zagardo@aecom.yu.edu.

Copyright $\odot 2003$ Society for Neuroscience $\quad$ 0270-6474/03/234208-11\$15.00/0 cently characterized receptor tyrosine kinase (RTK) family Axl/Mer/Rse.

The Axl/Mer/Rse RTK family members share a cell adhesion motif in the extracellular domain that in some cell types can signal via direct cell-cell contact or via its soluble ligand Gas6, a single membrane-spanning domain, and a cytoplasmic tyrosine kinase domain (Stitt et al., 1995; Varnum et al., 1995; McCloskey et al., 1997). Gas6 has the highest affinity for Axl, and in humans Gas6 is the sole ligand for these receptors (Li et al., 1996). Gas6 is expressed and secreted by neurons and endothelial cells; its widespread expression in the CNS suggests that the interaction between Gas6 and its receptor has a relevant physiological function (Li et al., 1996; Prieto et al., 2000). Gas6 signaling can induce varied responses in specific cell types. Gas6 is mitogenic for fibroblasts and Schwann cells (Goruppi et al., 1996; Li et al., 1996), whereas in rat hippocampal neurons, fibroblasts, and endothelial cells Gas6/Axl signaling protects from apoptosis induced by serum withdrawal or tumor necrosis factor- $\alpha$ (Goruppi et al., 1997; O’Donnell et al., 1999; Healy et al., 2001; Funakoshi et al., 2002).

We postulated that Gas6 would serve as a survival factor rather than as a mitogenic factor for human fetal oligodendrocytes. This hypothesis is based on the observation that during the second trimester of human fetal spinal cord development many oligodendrocytes in tissue are $2^{\prime}, 3^{\prime}$-cyclic nucleotide $3^{\prime}$ phosphodiesterase $^{+}\left(\mathrm{CNP}^{+}\right)$and myelin basic protein ${ }^{+}$ $\left(\mathrm{MBP}^{+}\right)$(Bodhireddy et al., 1994; Weidenheim et al., 1996), 
suggestive of a period of active and ongoing oligodendrocyte myelination. To test the role of Gas6 as a survival factor for oligodendrocytes, we established enriched oligodendrocyte primary cultures from human fetal spinal cord and analyzed them $6 \mathrm{~d}$ after the administration of Gas6.

\section{Materials and Methods}

Primary cell cultures: human fetal material, oligodendrocyte isolation, enrichment, and maturation. Human fetal spinal cord tissue was obtained from the Einstein Human Fetal Tissue Repository (New York, NY) as approved by the Institutional Review Board. Tissues from abortuses of normal women were collected after elective pregnancy termination. Informed consent was obtained from all tissue donors. The ages of the abortuses were determined by multiple parameters, including the date of the last menstrual period by history, uterine size by bimanual and abdominal examination, ultrasonography by using predominantly the maximum biparietal diameter, and, postabortally, by measurement of fetal foot length (Streeter, 1920; Hern, 1984). After retrieval of tissue the spinal cords were stored in sterile medium with antibiotics on ice and were obtained from the neuropathologist within the hour. For cultures the oligodendrocytes were obtained from 21-23 gestational weeks (gw) human fetal spinal cords. The meninges were removed completely, and the cord was dissected in a dish containing $\mathrm{Ca}^{2+} / \mathrm{Mg}^{2+}$-free HBSS (Invitrogen, Grand Island, NY). The minced tissue was incubated in prewarmed trypsin/EDTA solution $(0.025 \%$ trypsin and $0.1 \mathrm{~mm}$ EDTA; Sigma, St. Louis, MO) and shaken at $110 \mathrm{rpm}$ on an orbital shaker at $37^{\circ} \mathrm{C}$ for $20 \mathrm{~min}$. Trypsinization was terminated by adding a 1:1 vol of 25 $\mu \mathrm{g} / \mathrm{ml}$ soybean meal trypsin inhibitor (Sigma) for $5 \mathrm{~min}$ at room temperature. The tissue was spun at $1000 \mathrm{rpm}$ for $5 \mathrm{~min}$ and incubated in 80 $\mu \mathrm{g} / \mathrm{ml}$ DNase in HBSS containing $3.9 \% \mathrm{MgSO}_{4}$ for $10 \mathrm{~min}$ at $37^{\circ} \mathrm{C}$ to digest extracellular DNA. Then the tissue solution was triturated mechanically by being pipetted up and down 15 times. The cell suspension was centrifuged at $1000 \mathrm{rpm}$ for $5 \mathrm{~min}$ at room temperature, and the cell pellet was resuspended either in magnetic cell-sorting buffer (MACS; PBS, pH 7.2, supplemented with $0.5 \%$ bovine serum albumin and $2 \mathrm{~mm}$ EDTA; Miltenyi Biotech, Auburn, CA) for immunopanning (see below) or in N2 basal medium consisting of DMEM, N2 supplement [containing (in $\mathrm{mg} / \mathrm{ml}$ ) 0.5 insulin, 1 transferrin, 1.6 putrescine plus (in $\mu \mathrm{g} / \mathrm{ml}$ ) 0.5 selenite and 0.6 progesterone; Invitrogen], and penicillin/streptomycin at $100 \mathrm{U} / \mathrm{ml}$ and $0.1 \mathrm{mg} / \mathrm{ml}$, respectively, for culture studies. This medium hereafter is referred to as N2 basal medium. The suspended cells were transferred to a T75 flask and incubated overnight in a $5 \% \mathrm{CO}_{2}$, $37^{\circ} \mathrm{C}$ incubator to allow adherent cells, including microglia and type 1 astrocytes, to attach to the dish. Subsequently, nonadherent cells were collected and filtered through a cell strainer ( $40 \mu \mathrm{m}$ pore size; Falcon, Oxnard, CA) and centrifuged at $1000 \mathrm{rpm}$ for $5 \mathrm{~min}$. The pelleted oligodendrocytes were resuspended in N2 basal medium with $10 \mathrm{ng} / \mathrm{ml}$ platelet-derived growth factor (PDGF) and $5 \mathrm{ng} / \mathrm{ml}$ neurotrophin-3 (NT-3). Next, $5 \times 10^{4}$ cells were plated on 24 -well tissue culture wells containing the NIH3T3 or NIH3T3-Gas6 monolayer (Dormady et al., 2000) or on poly-L-lysine (Sigma)-coated LabTek II chamber slides (Fisher Scientific, Pittsburgh, PA) and treated with or without rhGas6. Cells were cultured at $37^{\circ} \mathrm{C}$ and $5 \% \mathrm{CO}_{2}$. To evaluate the number of cells that had adhered to the poly-L-lysine-coated wells, we fixed the cultures 1 $\mathrm{hr}$ after plating with $4 \%$ paraformaldehyde and stained them with hematoxylin. Counts of $20 \times$ objective microscopic fields that encompass all of the cells present in a culture well revealed the presence of $3 \times 10^{3}$ adherent cells. Immunocytochemistry performed on these cells indicated that $45 \%$ of the cells per well were $\mathrm{O}^{+}, 26 \%$ were $\mathrm{CNP}^{+}$, and $10 \%$ were $\mathrm{GFAP}^{+}$astrocytes. Cells were negative for NeuN and type III tubulin (neurons), CD68 (microglia), and vimentin (early astrocytes and endothelial cells). Thus the remaining 19\% of the cells that could not be accounted for with the standard cell-specific markers likely are human glial or neuronal progenitor cells for which markers are yet to be identified.

Soluble Axl-Fc was used to block the effect of recombinant human gas6 (rhGas6) and confirm specificity for the rhGas6/RTK interaction. TrkA-Fc was used as a negative control. The ectodomain of the receptors was fused to a spacer with the sequence Gly-Pro-Gly, followed by the hinge $\mathrm{CH} 2$ and $\mathrm{CH} 3$ regions of human IgG1. Proteins were expressed and purified as previously described (Stitt et al., 1995).

O4 immunopanning and magnetic-associated cell sorting. Highly enriched populations of oligodendrocytes from 18 and 22 gw human fetal spinal cord were used to perform the microarray analysis and identify genes expressed in differentiated fetal oligodendrocytes. The cell pellet containing oligodendrocytes resuspended in MACS buffer (Miltenyi Biotech) was incubated with the monoclonal antibody $\mathrm{O} 4$ for $15 \mathrm{~min}$ on ice as previously described (Gard et al., 1988; Gard and Pfeiffer, 1989; Pfeiffer et al., 1993). O4 (IgM) was selected as the primary antibody of choice for immunoselection because it is an oligodendrocyte-specific cell surface marker with no cross-reactivity to other cell types (Sommer and Schachner, 1981). Enriched O4 ${ }^{+}$oligodendrocytes were obtained after purification on IgM-conjugated magnetic microbeads and separated on a ferromagnetic column by positive cell selection (MACS; Miltenyi Biotech). This procedure does not disrupt the cellular integrity because it sorts live cells according to cell surface markers. RNA was isolated from the $\mathrm{O}_{4}{ }^{+}$oligodendrocytes by TRI-reagent (Molecular Research Center, Cincinnati, $\mathrm{OH}$ ) and was used for microarrays. $\mathrm{O}^{+}{ }^{+}$oligodendrocytes plated on LabTek slides and examined $3 \mathrm{~d}$ after plating to assess their purity by immunocytochemistry for CNP immunoreactivity indicated that a vast majority of the cultured cells were oligodendrocytes (98\%). The use of $\mathrm{O}^{+}$-immunopanned oligodendrocytes for microarray analysis rather that cultured cells guaranteed that the gene expression profile was not altered by added serum factors or trophic factors.

Microarray analysis. Microarray slides containing 8976 cDNA sequence-verified probes were used (Research Genetics, Huntsville, AL). Detailed descriptions of microarray hardware and procedures are available from http://129.98.70.229/. The 3DNA Submicro EX Expression Array detection kit (Genisphere, Montvale, NJ) was used as the amplification protocol to enhance the signal and enabled us to use $2 \mu \mathrm{g}$ of total RNA for the microarray analysis. The signal amplification is not based on amplification of RNA. Rather, the oligo-dT primers have Cy5 or Cy3 RT capture sequences that are used in signal enhancement. The 3DNA hybridization step relies on a 3DNA fluorescent probe that is complementary to the capture sequence. The 3DNA molecule contains $\sim 250$ fluorescent dyes per molecule versus the normal Cy incorporation of 2-30 dyes per cDNA molecule. After this step the microarrays are hybridized, washed, and scanned. The greater incorporation of Cy dye increases the signal and therefore reduces the amount of input total RNA that is required.

For each hybridization the cDNA targets were prepared from $2 \mu \mathrm{g}$ of the RNA sample (Cy5-labeled and Cy3-labeled) obtained from $\mathrm{O}^{+}{ }^{+}$. immunopanned oligodendrocytes at 18 and 22 gw. Reproducible results were obtained in three independent experiments with different RNA samples. The Cy5 or the Cy3 label was used on both samples, and the same result was obtained regardless of the label. Hybridization to cDNA arrays was performed overnight at $55^{\circ} \mathrm{C}$ in a hybridization buffer containing $0.25 \mathrm{M} \mathrm{NaPO}_{4}, 4.5 \%$ SDS, $1 \mathrm{~mm}$ EDTA, and $1 \times$ SSC. After hybridization the slides were washed for $13 \mathrm{~min}$ at $55^{\circ} \mathrm{C}$ with $2 \times \mathrm{SSC} / 0.2 \%$ SDS and at room temperature in $2 \times$ SSC and $0.2 \times$ SSC for $13 \mathrm{~min} /$ wash. Slides were dried immediately and scanned with a GenePix 4000A microarray scanner (Axon Instruments, Foster City, CA). Experiments were performed three independent times with RNAs isolated from $\mathrm{O}_{4}^{+}$. immunopanned oligodendrocytes from three independent spinal cords. Independent images were obtained for $\mathrm{Cy} 3$ and $\mathrm{Cy} 5$ fluorescence emitted from hybridized microarrays by using a custom-built dual channel laserscanning microscope. SCANALYZE version 2.44 software (M. Eisen, Stanford University, Palo Alto, CA) was used to generate raw data files containing measurements of signal and background fluorescence emissions of $\mathrm{Cy} 3$ and $\mathrm{Cy} 5$, respectively, for each element.

Signal and background intensities of each spotted cDNA element in Cy5 images were calibrated by a correction factor defined as $e^{\text {(mean } \ln C y 3)} /$ $e^{\text {(mean lnCy5)}}$, typically between 0.9 and 1.1 , to normalize for effects of global variations between Cy3 and Cy5 fluorescence intensities in each hybridized array. Net signal intensity (NSI) in each channel (Cy3 and Cy5) was determined by subtracting the local background from signal intensity values. Typically, values of 250-400 were considered back- 
ground. Negative NSI values were set to the smallest intensity unit equal to 1. Signal-to-noise $(\mathrm{S} / \mathrm{N})$ threshold criteria for genes to pass as "expressed" were set independently for both Cy3 and Cy5 channels. Elements with $\mathrm{S} / \mathrm{N}>1+(=1 \mathrm{SD}$ of the mean of background values in each hybridized array divided by the mean of background values; typically 0.15-0.30) in either Cy3 or Cy5 or both channels, respectively, were considered well measured and expressed. Elements with $\mathrm{S} / \mathrm{N}<1+$ in both channels were flagged (marked as nonexpressed). The value was determined for each hybridized array to account for variations in global signal and background intensities between individual experiments.

$R T$-PCR analysis. $\mathrm{O}^{+}{ }^{+}$oligodendrocytes were obtained from $22 \mathrm{gw}$ human fetal spinal cords by immunopanning and MACS as described earlier. Total RNA was prepared from the $\mathrm{O}^{+}$cells by the acidguanidinium method with Trizol. cDNA was prepared from $1.4 \mu \mathrm{g}$ of total RNA with oligo-dT by Superscript II reverse transcriptase in the SuperScript II kit (18064-014, Life Technologies) according to the manufacturer's instructions. Total RNA (342 ng) was used in a $50 \mu$ l reaction containing (in mM) 20 Tris- $\mathrm{HCl}, \mathrm{pH} 8.4,50 \mathrm{KCl}, 2.5 \mathrm{MgCl}_{2}$, and 0.4 dNTPs plus $5 \mathrm{U} / \mu \mathrm{l}$ AmpliTaq gold (PerkinElmer Applied Biosystems, Emeryville, CA) for quantification of cDNA species by PCR analysis. Amplification of Axl/Rse/Mer cDNA was performed with $0.2 \mathrm{~mm}$ of the following primers:

Axl sense (33mer), 5' -CTGGTGCTTGGCGCTGTGCGGCTGGGCCTGCAT-3'; Axl antisense (21mer), 3'-CTTGGACTCTAGAGTCTTGGA-5'; Rse sense (21mer), 5' -CTCCCGCCGCTGCCGCTGCCG-3'; Rse antisense (23mer), 3' -GATGTTCTCCAGTTCCATTCGCA-5'; Mer sense (24mer), 5' -CTGACCACACACCGCTGTTATCCC-3'; Mer antisense (22mer), 3'-CATTCATCTGGTGCTTTGCCCC-5' .

Reaction conditions included an initial denaturation step $\left(95^{\circ} \mathrm{C}\right.$ for 10 min), followed by 33 cycles of $95^{\circ} \mathrm{C}$ for $30 \mathrm{sec}, 55^{\circ} \mathrm{C}$ for $90 \mathrm{sec}$, and $70^{\circ} \mathrm{C}$ for $2 \mathrm{~min}$. A final extension step $\left(72^{\circ} \mathrm{C}\right.$ for $\left.10 \mathrm{~min}\right)$ concluded the reaction. PCR products (one-third of the reaction) were analyzed electrophoretically on $1 \%$ agarose gels poured and run in $1 \times$ Tris borate-EDTA. PCR products were excised from the gel, eluted, and sequenced to confirm the presence of Axl/Mer/Rse.

Western blot analysis. Total protein homogenates were prepared from 22 gw human fetal spinal cords or the human oligodendroglioma TC620 (Kashima et al., 1993), analyzed by SDS-PAGE on 10\% gels as previously described (Laemmli, 1970; Albala et al., 1995), and transferred electrophoretically to nitrocellulose (Towbin et al., 1979). Immunoblots were blocked with $5 \%$ nonfat dry milk in $1 \times$ Tris-buffered saline $(1 \times$ TBS; $0.14 \mathrm{M} \mathrm{NaCl}, 0.001 \mathrm{~m}$ Tris, $\mathrm{pH}$ 7.4). Blots were incubated with an Axl polyclonal antibody (1:250; Amgen, Thousand Oaks, CA) overnight at $4^{\circ} \mathrm{C}$ and visualized by enhanced chemiluminescence (ECL; Amersham Biosciences, Arlington Heights, IL).

Immunocytochemistry for $\mathrm{O} 4 \mathrm{CNP}$, and $\mathrm{MBP}$. Oligodendrocytes were plated at $5 \times 10^{4}$ cells/well in a 24-well tissue culture plate containing $5 \times$ $10^{4}$ irradiated NIH3T3 cells expressing Gas6 or on irradiated NIH3T3 cells. Cells also were plated on poly- L-lysine-coated chamber slides or 24-well tissue culture plates and treated with or without rhGas6. After $6 \mathrm{~d}$ the cells were fixed in $4 \%$ paraformaldehyde for $30 \mathrm{~min}$, permeabilized with $0.25 \%$ Triton $\mathrm{X}-100$ in $1 \times \mathrm{TBS} / 3 \%$ hydrogen peroxide, and blocked in $10 \%$ goat serum in $5 \%$ nonfat dry milk/1× TBS for $1 \mathrm{hr}$. After being washed, the cells were incubated in the primary antibodies overnight in a humid chamber at $4^{\circ} \mathrm{C}$. The $\mathrm{O} 4$ antibody (Bansal et al., 1989) was used routinely at 1:25 and the CNP antibody (Raible and McMorris, 1989) at 1:500. After being rinsed, they were incubated in the corresponding biotinylated secondary antibodies (rabbit anti-mouse IgM or goat antirabbit IgG; Southern Biotechnology Associates, Birmingham, AL), diluted 1:200 in 5\% milk/1× TBS, washed, and incubated in the ABC complex (Vector Laboratories, Burlingame, CA). Bound peroxidase was revealed as a brown reaction product via $0.03 \% 3,3^{\prime}$-diaminobenzidine (DAB; Sigma).

O4/Axl double-label immunofluorescence and microscopy of oligodendrocyte cultures. Cells were fixed and blocked as above and incubated with an affinity-purified Axl polyclonal antibody (1:250; Amgen) overnight at $4^{\circ} \mathrm{C}$, followed by the appropriate biotinylated secondary antibody. Subsequently, the cells were washed and incubated with streptavidin Alexa 488 (1:500; Molecular Probes, Eugene, OR) in 5\% milk/1× TBS for $1 \mathrm{hr}$ at room temperature. Consequent to Axl labeling the cells were incubated with the $\mathrm{O} 4$ monoclonal antibody $(1: 25)$ overnight at $4^{\circ} \mathrm{C}$, followed by biotinylated IgM (1:200) for $1 \mathrm{hr}$ at room temperature. Cells were washed and incubated with streptavidin Alexa 568 in 5\% milk/1X TBS for $1 \mathrm{hr}$. Cells were mounted with Aquamount (Biomeda, Foster City, CA). All samples were examined under an Olympus (Melville, NY) $1 \times 70$ with a $20 \times$ numerical aperture 1.0 or a $60 \times$ numerical aperture 1.0 Plan Apo optics inverted microscope with a Photometrics (Roper Scientific, Tucson, AZ) Censys-cooled CCD camera; images were collected on a Macintosh G3 with IPLab Spectrum software (Scanalytics, Fairfax, VA).

Immunohistochemistry and confocal microscopy of human fetal spinal cord sections. Human fetal spinal cord (21 gw) was freed of meninges and dissected into cervical, thoracic, and lumbar regions; $\sim 2-3 \mathrm{~mm}$ crosssectional segments were flash-frozen in O.C.T. (Tissue-Tek; Miles, Elkhart, IN) by a dry ice isopentane bath. Cryostat serial sections $(7 \mu \mathrm{m})$ from the lumbar region were mounted on positively charged glass slides, dried, and baked for $30 \mathrm{~min}$ at $60^{\circ} \mathrm{C}$. At room temperature the sections were air-dried for $10 \mathrm{~min}$, fixed in $4 \%$ paraformaldehyde for $10 \mathrm{~min}$, and washed twice in $1 \times$ TBS. Antigen retrieval was performed by boiling the sections in $1 \times$ TBS in a microwave for $7 \mathrm{~min}$ on power 7 . To eliminate autofluorescence and eliminate nonspecific staining, we incubated sections in $0.15 \mathrm{M}$ glycine in $1 \times \mathrm{TBS}$ for $20 \mathrm{~min}(2 \times)$, washed them twice in $1 \times$ TBS for $5 \mathrm{~min}$ each, incubated them with $0.25 \%$ Triton X-100 in $1 \times$ TBS for $30 \mathrm{~min}$, and blocked them in 2\% BSA and 10\% goat serum (Vector Laboratories) for $1 \mathrm{hr}$. All primary antibodies were diluted in 2\% $\mathrm{BSA} / 5 \%$ goat serum and sequentially incubated overnight at $4^{\circ} \mathrm{C}$. Sections were incubated with the affinity-purified Axl polyclonal antibody (1:200; Amgen) in the presence and absence of $20 \mu \mathrm{g}$ of Axl-Fc; the fluor was Alexa 568. O4 was used as above with streptavidin Alexa 647 as the fluor. Monoclonal antibody 13.10 (1:10; IgG1) identifies the early oligodendrocyte-specific MAP-2 isoform MAP-2 +13 and was used with Alexa 647. The $\mathrm{O} 4$ antibody recognizes a glycolipid on the oligodendrocyte cell surface. The MAP-2 + 13 antibody stains the oligodendrocyte cell body and processes (Shafit-Zagardo et al., 1999, 2000). Immunofluorescence was performed as above. All images were collected in $z$-series, using a Bio-Rad (Hercules, CA) MRC 600 laser-scanning confocal microscope. To ensure no cross talk from one fluorescent channel to another, we collected each channel in the lambda-scanning sequential mode with independent excitation and emission detection through its own narrow band filter.

Data analysis. All data were analyzed by Prism 2.01 software (GraphPad Software, San Diego, CA). For individual comparisons the unpaired Student's $t$ test at $99 \%$ confidence was used. Significances also were assessed by the $\chi^{2}$ test for the data shown in Table 2 and Figure 6.

Bromodeoxyuridine labeling and immunostaining. Oligodendrocytes were incubated for $6 \mathrm{~d}$ with or without rhGas 6 in N2 basal medium with PDGF and NT-3 containing $50 \mu \mathrm{M}$ bromodeoxyuridine (BrdU; Amersham Biosciences). Then the cells were fixed and immunostained for $\mathrm{O} 4$ or CNP as described earlier. Cells were treated with $2 \mathrm{~N} \mathrm{HCl} \mathrm{(40} \mathrm{min)} \mathrm{and}$ incubated with an anti-BrdU monoclonal antibody (1:200; BD Biosciences, San Diego, CA) in 5\% milk/1× TBS containing 0.1\% Triton $\mathrm{X}-100$ overnight at $4^{\circ} \mathrm{C}$. Subsequently, after incubation in the appropriate biotinylated secondary antibody, the cells were washed and incubated with streptavidin Alexa 568 or streptavidin Alexa 488 in 5\% milk/1× TBS for $1 \mathrm{hr}$. For each treatment in duplicate wells 25 random $20 \times$ objective fields were examined. This consisted of $\sim 1000$ total cells. $\mathrm{O}^{+} / \mathrm{BrdU}^{+}$ or $\mathrm{CNP}^{+} / \mathrm{BrdU}^{+}$cells were counted, and the results were expressed as the number of $\mathrm{O}^{+} / \mathrm{BrdU}^{+}$or $\mathrm{CNP}^{+} / \mathrm{BrdU}^{+}$cells relative to the total number of $\mathrm{O}^{+}{ }^{+}$or $\mathrm{CNP}^{+}$cells per individual $20 \times$ field.

Terminal deoxynucleotidyl transferase-mediated biotinylated UTP nick end-labeling assay. TUNEL staining was performed to assess apoptotic cell death in the minus and plus Gas6-treated oligodendrocytes by the Fluorescein In Situ Cell Death detection kit (Roche Molecular Biochemicals, Indianapolis, IN). The TUNEL reaction preferentially labels cleaved genomic DNA generated during apoptosis by the addition of fluorescein dUTP at strand breaks. Oligodendrocytes after $6 \mathrm{~d}$ of treatment were fixed and permeabilized as described above for immunocytochemistry. Cells were washed and incubated in the TUNEL reaction mixture, pre- 
Table 1. Genes for kinases expressed in $04^{+}$cells

\begin{tabular}{|c|c|c|c|}
\hline Accession number & Gene name & $18 \mathrm{gw}$ & $22 \mathrm{gw}$ \\
\hline H15718 & AXL receptor tyrosine kinase & $3172(12.7)$ & $2815(11.3)$ \\
\hline AA436591 & Human c-mer & $3734(14.9)$ & $2608(10.4)$ \\
\hline AA464765 & Phosphatidylinositol 3-kinase, catalytic, gamma polypeptide & $2956(11.8)$ & $2406(9.6)$ \\
\hline AA476263 & H. sapiens phosphorylase-kinase, $\beta$ subunit & $3983(15.9)$ & $3330(13)$ \\
\hline AA676749 & Dual-specificity tyrosine phosphorylation-regulated kinase & $3606(14.4)$ & $3596(14.4)$ \\
\hline H17504 & H. sapiens ERK3 & $2168(8.7)$ & $2416(9.7)$ \\
\hline N23898 & G-protein-coupled receptor kinase (GRK4) & $3085(12.2)$ & $3098(12.4)$ \\
\hline T50313 & Human hematopoietic progenitor kinase (HPK 1) & $1497(6.0)$ & $1933(7.7)$ \\
\hline T57805 & Human Rho-associated, coiled coil-containing protein kinase p160R0CK & $1523(6.1)$ & $1638(6.6)$ \\
\hline
\end{tabular}

List of kinases for which transcripts were elevated more than fourfold in $04^{+}$cells derived from spinal cord tissues at 18 and 22 gestational weeks (gw). Values in parentheses represent fold increase over baseline reading.

pared according to the manufacturer's recommendations, for $1 \mathrm{hr}$ at $37^{\circ} \mathrm{C}$. Omission of the terminal deoxynucleotidyl transferase in the label solution served as a negative control for the TUNEL staining. Cells were examined with an Olympus IX70 inverted microscope. For each treatment 25 random $20 \times$ objective fields consisting of $\sim 1000$ cells in total were examined in duplicate wells of 24-well tissue culture plates. $\mathrm{O} 4$ or $\mathrm{CNP}^{+} / \mathrm{TUNEL}^{+}$nuclei were expressed as a percentage of the total number of $\mathrm{O}^{+}$or $\mathrm{CNP}^{+}$cells per individual field.

PI-3 kinase and mitogen-activated protein kinase inhibition assay. At plating $400 \mathrm{ng} / \mathrm{ml}$ rhGas6 was added to oligodendrocytes and incubated for $6 \mathrm{~d}$ in $500 \mu \mathrm{l}$ of $\mathrm{N} 2$ basal medium containing PDGF and NT-3 and in the presence and absence of the PI-3 kinase inhibitors, LY294006 (10 nM) or wortmannin $(100 \mathrm{nM})$, or the mitogen-activated protein kinase kinase 1/2 (MEK 1/2) inhibitor U0126 (10 $\mu \mathrm{M}$; Promega, Madison, WI). Control cultures received either N2 basal medium containing PDGF, NT-3, and rhGas6 or N2 basal medium. After $6 \mathrm{~d}$ the oligodendrocytes were fixed, and immunofluorescent staining for CNP or O4 was performed, followed by TUNEL staining. For each treatment 25 random $20 \times$ objective fields consisting of $\sim 1000$ cells were examined in duplicate wells of 24-well tissue culture plates. $\mathrm{O}^{+} / \mathrm{TUNEL}^{+}$or $\mathrm{CNP}^{+} / \mathrm{TUNEL}^{+}$cells were expressed as a percentage of the total number of $\mathrm{O}^{+}{ }^{+} \mathrm{or} \mathrm{CNP}^{+}$cells per individual field.

\section{Results}

An inability to grow and maintain human fetal oligodendrocytes in cultures forced us to consider other approaches to identify trophic or survival factors for human oligodendrocytes. Microarrayed slides containing 8976 human cDNAs with $\sim 10 \%$ of the cDNAs expressed in the nervous system provided us with a means of identifying novel receptors or signaling molecules expressed in fetal oligodendrocytes. Human fetal oligodendrocytes were purified from spinal cord by immunopanning with the oligodendrocyte-specific surface marker antibody O4. An average (obtained from six separate fetal spinal cords from 18-23 gw) of $10^{6}$ suspended cells was obtained immediately before $\mathrm{O} 4$ immunopanning. After $\mathrm{O} 4$-positive $\left(\mathrm{O}_{4}{ }^{+}\right)$immunopanning an average of $7 \times 10^{5} \mathrm{O}^{+}$oligodendrocytes $(\sim 7 \%$ of the starting enriched population) was recovered. RNA isolated from $\mathrm{O}^{+}$ cells at 18 and 22 gw was used for microarray analysis.

Three independent microarray analyses were performed by comparing cDNAs expressed in $\mathrm{O}_{4}{ }^{+}$-immunopanned oligodendrocytes isolated from human fetal spinal cord at 18 and $22 \mathrm{gw}$. The purity of the cell populations used for generating the $\mathrm{O}^{+}$ RNA was determined by examining the arrays for the presence of known microglial, astrocytic, or neuronal markers. For microglia, 14 CD cDNAs for CD49b, CD11a and c, CD32, CD64, CD68, CD45, CD8, CD48, CD86, CD83, CD63, CD31, and CD18 were examined and were all below the baseline value. For astrocytes, apolipoprotein $\mathrm{E}$ and monoamine oxidases $\mathrm{A}$ and $\mathrm{B}$, known astrocytic messages, were also negative. To address further possible astrocytic contamination, we performed RT-PCR by using primers for GFAP and vimentin with cDNA from O $44^{+}$and $\mathrm{O} 4^{-}$cells.
The results showed that, whereas RNA derived from the $\mathrm{O}^{-}$cell population indeed did contain transcripts for both vimentin and GFAP, RNA derived from the $\mathrm{O}^{+}{ }^{+}$cell population did not. These data rule out both astrocytic and endothelial cell contamination of the $\mathrm{O}^{+}{ }^{+}$RNA, because vimentin is expressed in endothelial cells also. Examination of the arrays for expression of genes for the three neurofilament proteins NF-L, NF-M, and NF-H indicated that the $\mathrm{O}_{4}{ }^{+}$cells were negative for these genes, with values equivalent to background. In contrast, examination of the arrays for genes known to be present in oligodendrocytes demonstrated the presence of signal more than fourfold above background for MBP (accession number H17696), the Pou homeobox protein (accession number N63968, also known as transcription factor Brain5), and butyrylcholine esterase (accession number AA885311) in both the 18 and 22 gw samples.

Analysis of the array data for receptor and kinase signaling path-
A $\begin{array}{lllll}1 & 2 & 3 & 4 & 5\end{array}$ $2.9 \mathrm{~kb}=-3.5 \mathrm{~kb}$ C $\mathrm{kDa} 112230456$

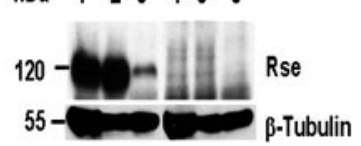

B

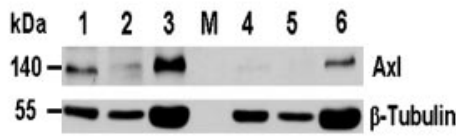

D

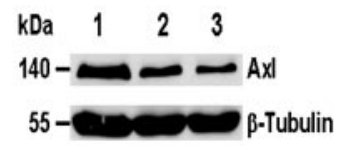

Figure 1. Axl/Mer/Rse are expressed in human fetal spinal cord oligodendrocytes. cDNA was prepared from $04^{+}$oligodendrocyte RNA at $22 \mathrm{gw}$ and the human oligodendroglioma TC620 cells. The Axl and Rse primers are near the start site and stop within the $3^{\prime}-$ UTR. A, Axl (lane 1), Rse (lane 3), and Mer (lane 5) are expressed in $04^{+}$oligodendrocytes. Axl and Rse are expressed in TC620 cells also (lanes 2, 4, respectively); Mer was not examined in TC620 cells. B, C, Western blot analysis confirmed the presence of Axl and Rse in human fetal spinal cord at $22 \mathrm{gw}$. Total protein homogenates $(20-50 \mu \mathrm{g})$ from two human oligodendrogliomas, TC620 cells (lanes 1, 4) and HOG cells (lanes 2,5), and human fetal spinal cord (22 gw; lanes 3, 6) were analyzed for the expression of $A x I(B)$ and Rse ( $($ ). Preincubation of the Axl antibody (1:250) with $20 \mu \mathrm{g} / \mathrm{ml}$ $\operatorname{Axl}-\mathrm{Fc}(B$, lanes $4-6)$ or the preincubation of the Rse antibody (1:100) with its blocking peptide reduced immunoreactivity $(C$, lanes $4-6)$. $M$, Marker lane (in $B)$. To verify protein loading in each lane, we stripped and incubated the blots with a $\beta$-tubulin monoclonal antibody (1:1000). Visualization is by ECL. D, Analysis of Axl receptor expression during human fetal spinal cord development. Lanes 1-3 contain $50 \mu \mathrm{g}$ of total protein isolated from human fetal spinal cord at 18,20 , and $22 \mathrm{gw}$, respectively. First the blot was incubated with the affinity-purified Axl polyclonal antibody (1:250; Amgen) overnight at $4^{\circ} \mathrm{C} ;$ so that equal loading could be confirmed, the blot was stripped and incubated with a $\beta$-tubulin monoclonal antibody (1:1000). Blots were scanned in a linear range; the data are presented as a ratio of Axl over $\beta$-tubulin. The relative quantities of the $140 \mathrm{kDa}$ Axl were $18 \mathrm{gw}$ (lane 1), $0.528 ; 20 \mathrm{gw}$ (lane 2), 0.287; $22 \mathrm{gw}$ (lane 3), 0.160 . 
ways likely to be involved in regulating oligodendrocyte survival demonstrated a strong signal for Axl and Mer as well as seven other kinases (Table 1). Axl and Mer belong to the same receptor tyrosine kinase family consisting of Axl, Rse, and Mer (Axl/Ufo/Ark/Tyro7, Rse/Tyro3/Sky/Brt/Tif, and Mer/Nyk/ Eyk/Tyro12) (Janssen et al., 1991; Lai and Lemke, 1991; O’Bryan et al., 1991; Rescigno et al., 1991; Faust et al., 1992; Jia et al., 1992; Dai et al., 1994; Fujimoto and Yamamoto, 1994; Graham et al., 1994; Jia and Hanafusa, 1994; Lai et al., 1994; Ohashi et al., 1994; Ling and Kung, 1995). Axl and Mer expression was 11- to 12-fold above background and was among the $\mathrm{cDNAs}$ further studied. The third family member, Rse, was not on the array; however, RT-PCR performed with CDNA prepared from purified $22 \mathrm{gw} \mathrm{O}^{+}$ oligodendrocyte RNA demonstrated the presence of transcripts for Axl, Mer, and Rse receptors (Fig. 1A). A 2.9 kb Axl product and a $2.3 \mathrm{~kb}$ Rse product were observed in the $\mathrm{O} 4{ }^{+}$oligodendrocyte cDNA (lanes 1,3 , respectively) and in cDNA isolated from the human oligodendroglioma cell line TC620 (lanes 2, 4). A $3.5 \mathrm{~kb}$ Mer product was detected in the $\mathrm{O}_{4}^{+}$oligodendrocyte cDNA (Fig. 1A, lane 5).

Immunoblots containing protein homogenates prepared from two human oligodendrogliomas and from human fetal spinal cord at $22 \mathrm{gw}$ demonstrated that the $140 \mathrm{kDa}$ Axl receptor and the $120 \mathrm{kDa}$ Rse are expressed (Fig. 1B,C, lanes 1-3). Specificity was verified by adsorbing the Axl antibody with Axl-Fc and the Rse antibody with its blocking peptide (Fig. $1 B, C$, lanes 4-6). A commercially available Mer antibody yielded uninterpretable results, and an antibody to chick Mer did not recognize the human protein (obtained from Drs. Hirokawa and Georgescu, Rockefeller University, New York, NY). To determine whether Axl receptor expression varies during human fetal spinal cord development, we incubated blots containing total protein homogenates from human fetal spinal cord at 18, 20, and 22 gw with the Axl antibody. The $140 \mathrm{kDa}$ Axl receptor was expressed at all of the developmental ages that were analyzed (Fig. $1 D$ ). To confirm that Axl is expressed on oligodendrocytes, we performed single and double-label immunofluorescence and confocal microscopy with the Axl polyclonal antibody and antibodies to two well characterized oligo-

dendrocyte markers, O4 and MAP-2 + 13. As shown in Figure 2, Axl is expressed on oligodendrocytes within the white matter of spinal cord. Cross sections of the lumbar region at $21 \mathrm{gw}$ demonstrate that a high percentage of the oligodendrocytes expresses Axl on the cell body and processes (Fig. 2A). Oligodendrocytes positive for O4 (Fig. $2 B$ ) and MAP-2 + 13 (Fig. 2C) were also positive with Axl (Fig.
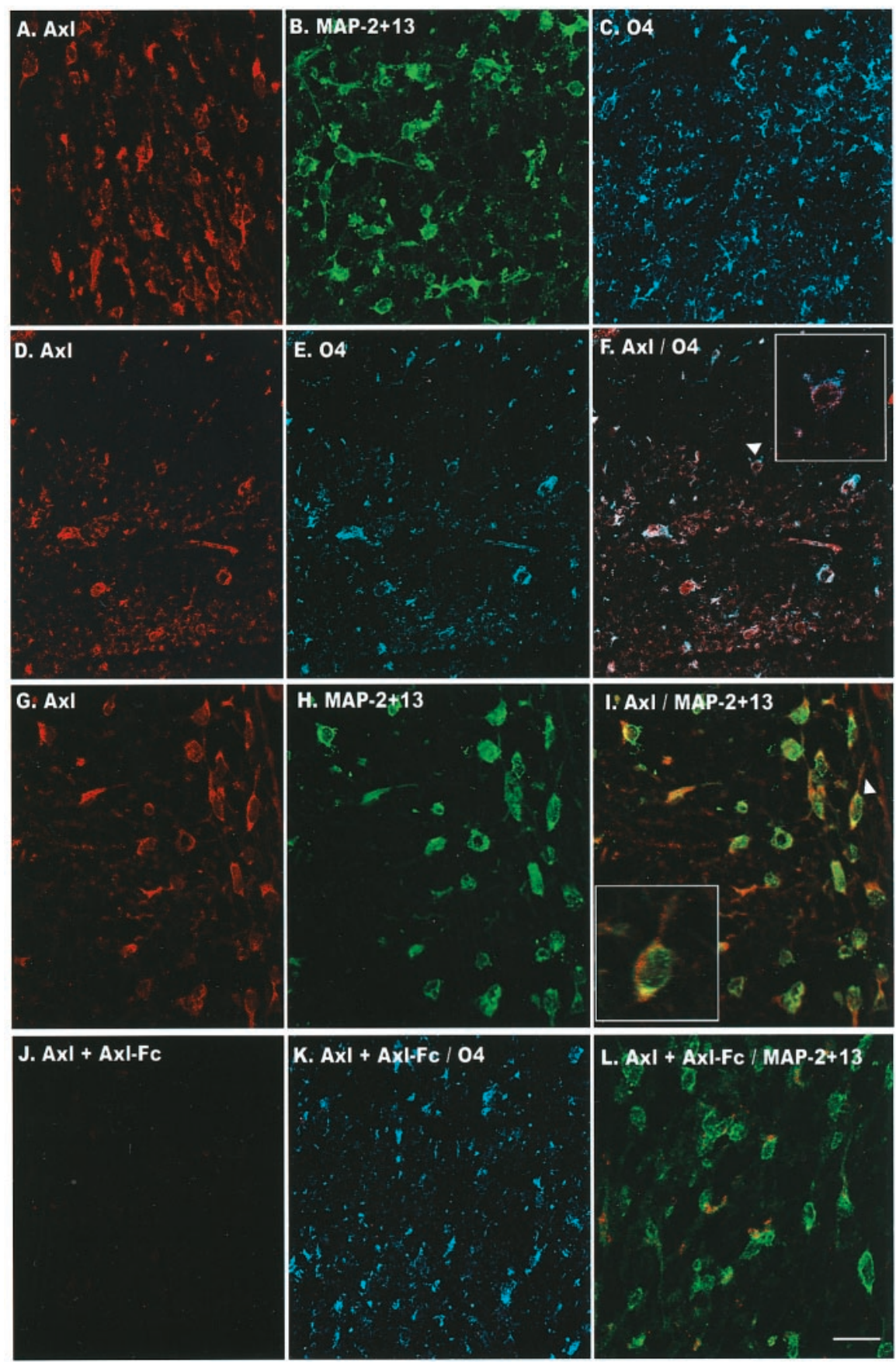

Figure 2. Axl is expressed on oligodendrocytes in fetal spinal cord at $21 \mathrm{gw}$. Maximum pixel projection of $\mathrm{z}$-series images was obtained by confocal microscopy of the white matter from the lumbar region. $A-C$, Single staining of the polyclonal antibody to $\operatorname{Axl}(A)$ and a monoclonal antibody to MAP-2 $+13(B)$ and to $04(C) \cdot D-F$, Double-label immunofluorescence of Axl (red fluor Alexa 568) and 04 (blue fluor Alexa 647). G-I, Double-label immunofluorescence of Axl (red fluor Alexa 568) and MAP-2 + 13 (Alexa 647 fluor is shown as green in the images). Arrowheads in $F$ and $/$ denote a higher magnification of the double-labeled oligodendrocyte in the inset boxes. Axl staining was always performed first. J, Preincubation of the Axl antibody with Axl-Fc before incubation eliminated Axl staining. Double-label immunofluorescence of adsorbed Axl antibody with 04 ( K) or MAP-2 + 13 (L) detected staining with only the respective monoclonal antibody. No cross-reactivity was observed when the 04 or MAP- $2+13$ monoclonal antibody was eliminated and the respective secondary antibody and fluor were included (data not shown). Scale bar, $20 \mu \mathrm{m}$.

$2 D-F, G-I$, respectively). Preincubation of the Axl antibody with Axl-Fc eliminated Axl staining (Fig. $2 J$ ), but not O4 (Fig. $2 \mathrm{~K}$ ) or MAP-2 + 13 (Fig. 2L). Thus the RT-PCR data, immunoblotting, and immunofluorescence studies support our microarray results that Axl is expressed on oligodendrocytes in the human fetal spinal cord. 
A.

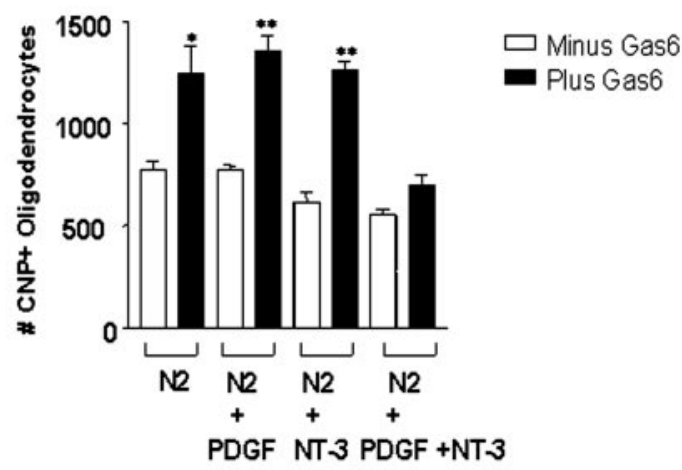

B.

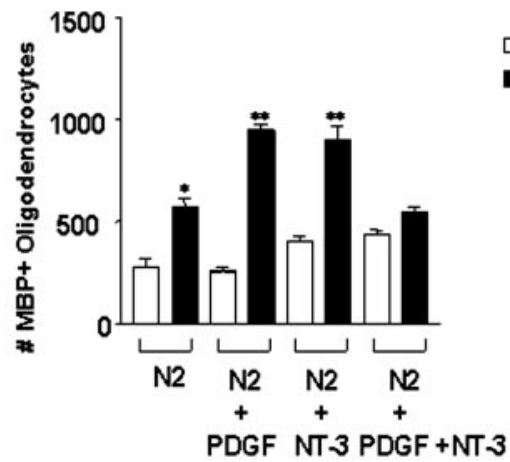

Figure 3. The number of $\mathrm{CNP}^{+}$and $\mathrm{MBP}^{+}$human oligodendrocytes is increased when plated on irradiated NIH3T3 cells secreting Gas6. NIH3T3 cells with and without Gas6 were plated at a density of $5 \times 10^{4}$ cells in 24-well plates. After $24 \mathrm{hr}$ the NIH3T3 cells were $\gamma$-irradiated at 12,500 rads to prevent cell division but permitted the secretion of Gas 6 into the medium from the NIH3T3-Gas6 cells. Enriched oligodendrocytes isolated from $20-23 \mathrm{gw}$ human fetal spinal cord were plated on the irradiated $3 T 3$ cells. N2 basal medium and $10 \mathrm{ng} / \mathrm{ml}$

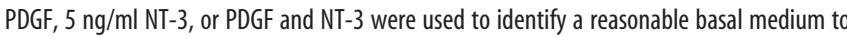
support the oligodendrocytes in the presence and the absence of Gas6. After $6 \mathrm{~d}$ in culture the oligodendrocyte-3T3 cocultures with or without Gas 6 were fixed and immunostained with antibodies to CNP and MBP. Data represent the number of $\mathrm{CNP}^{+}$and $\mathrm{MBP}^{+}$oligodendrocytes counted from duplicate wells. Each error bar represents the mean \pm SEM $(n=6)$ obtained from three independent experiments $\left({ }^{* *} p<0.01 ;{ }^{*} p<0.05\right.$; unpaired Student's $t$ test).

Gas6 is the sole ligand for the human Axl/Mer/Rse RTK family (Li et al., 1996). Initially, we tested the effect of Gas6 by culturing the oligodendrocytes on NIH3T3 cells secreting Gas6. A $2.0 \mathrm{~kb}$ gas6 RT-PCR product confirmed Gas6 expression in the NIH3T3-Gas6 cells (data not shown). NIH3T3 cells with and without Gas6 were irradiated to prevent cell division, thereby providing a support for oligodendrocytes and permitting the secretion of Gas6 into the medium from the NIH3T3-Gas6secreting cells. N2 basal medium supplemented with PDGF, NT-3, or PDGF and NT-3 was used to identify a reasonable basal medium to support the oligodendrocytes in the presence and the absence of Gas6. As shown in Figure 3, oligodendrocytes plated on Gas6-secreting 3T3 cells in N2 basal medium, N2 plus PDGF, and N2 plus NT-3 all demonstrated a statistically significant twofold increase in the number of $\mathrm{CNP}^{+}$oligodendrocytes and a two- to threefold increase in $\mathrm{MBP}^{+}$oligodendrocytes relative to oligodendrocytes plated solely on irradiated NIH3T3 cells. Gas6 had no effect on oligodendrocyte cell number when plated on Gas6-secreting 3T3 cells in N2 basal medium containing PDGF and NT-3. This was surprising because, as part of this study, we had determined that oligodendrocytes plated on poly-L-lysine survive best in N2 basal medium containing PDGF and NT-3 as opposed to each factor alone or in combination with IGF-1, FGF- $\beta$, neuregulin, or GDNF (data not shown). Morphological

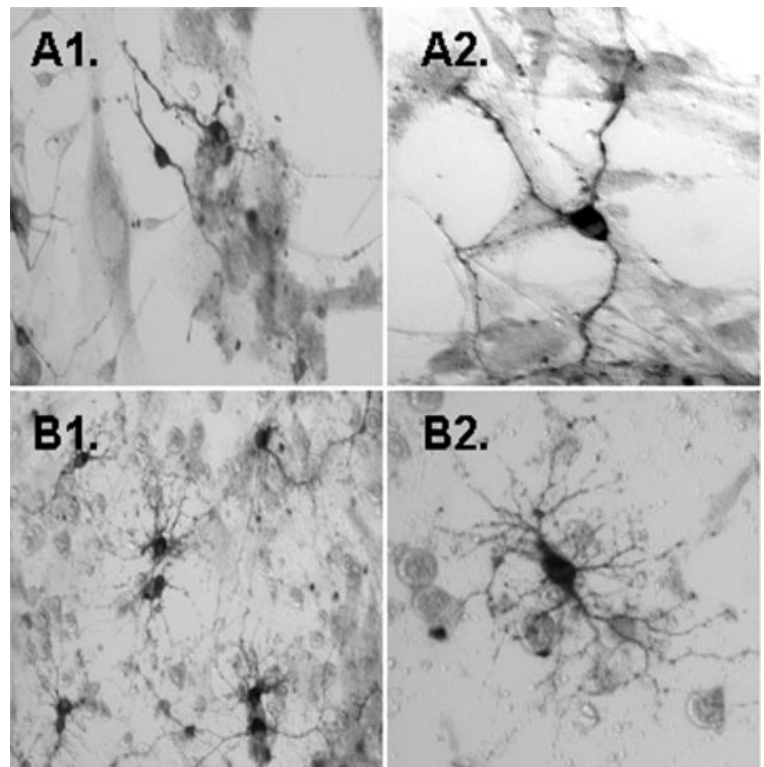

Figure 4. Increased primary and secondary $\mathrm{CNP}^{+}$oligodendrocyte processes when plated on irradiated NIH3T3 cells secreting Gas6. Shown are photomicrographs of $6 \mathrm{~d}$ oligodendrocyte cell cultures plated on NIH3T3 cells $(A 1, A 2)$ or plated on irradiated NIH3T3 cells secreting Gas6 $(B 1, B 2)$ in N2 basal medium containing PDGF. Immunocytochemistry of oligodendrocytes was performed with antibodies against CNP. Visualization was by DAB. Oligodendrocytes plated on Gas6-secreting NIH3T3 cells demonstrated a twofold increase in the number of CNP ${ }^{+}$oligodendrocytes $(B 1, B 2)$ relative to oligodendrocytes plated on irradiated NIH3T3 cells $(A 1, A 2)$. Morphologic examination of the CNP ${ }^{+}$oligodendrocytes plated on the Gas6-secreting NIH3T3 cells in N2 basal medium alone or supplemented with PDGF, NT-3, or PDGF and NT-3 media indicated that the oligodendrocytes showed increased numbers of primary and secondary processes (B2, Table 2). $A 1, B 1$, Magnification, 20X;A2, B2, magnification, $60 \times$.

examination of the oligodendrocytes in all four media indicated that the oligodendrocytes plated on the Gas6-secreting NIH3T3 cells showed increased numbers of primary and secondary processes (Fig. 4, Table 2).

To determine whether the medium from irradiated Gas6secreting cells was sufficient to increase $\mathrm{CNP}^{+}$and $\mathrm{MBP}^{+}$cell number, we plated enriched oligodendrocyte cultures from human fetal spinal cord and from postnatal rat cortex on poly-Llysine-coated 24-well tissue culture plates and the cultures received spent medium from the Gas6-secreting cells for $6 \mathrm{~d}$. In the human and rat oligodendrocyte cultures a two- to threefold increase in $\mathrm{CNP}^{+}$oligodendrocytes was observed in the presence of the Gas6-containing medium relative to the medium from irradiated non-Gas6-secreting NIH3T3 cells. However, the human oligodendrocytes were not $\mathrm{MBP}^{+}$. To test whether the human oligodendrocytes required both Gas6 and the support from the NIH3T3 cells to express MBP, we plated oligodendrocytes on nonirradiated, non-Gas6-secreting NIH3T3 cells in the presence of $400 \mathrm{ng} / \mathrm{ml}$ rhGas6 in N2 basal medium without additional trophic support and examined them for CNP and MBP immunoreactivity $6 \mathrm{~d}$ after plating. Again the oligodendrocytes were not $\mathrm{MBP}^{+}$, but there was a twofold increase in $\mathrm{CNP}^{+}$cells in the presence of Gas6 consistent with the 1.6-fold increase observed when the oligodendrocytes were plated on $3 \mathrm{~T} 3$ cells secreting Gas6 in N2 basal medium. Unlike the co-plating studies in which there was a twofold increase in the number of $\mathrm{MBP}^{+}$cells, MBP was not detected in the oligodendrocytes plated on poly-Llysine, suggesting that perhaps the Gas6-secreting 3T3 cells express an additional, as yet unidentified, factor that in addition to cell-cell contact induces MBP expression. 
Table 2. Gas6 enhances oligodendrocyte arborization

\begin{tabular}{llll}
\hline & N2 & N2 + PDGF & N2 + NT3 \\
\hline Number of primary processes & $+p=0.003$ & NS & $++p=0.001$ \\
Number of secondary processes & $++p=0.0013$ & $+++p=<0.0001$ & $+++p=<0.0001$ \\
Length of the longest process & NS & $+p=0.0027$ & $++p=<0.0001$ \\
\hline
\end{tabular}

Human fetal oligodendrocytes were plated on irradiated NIH3T3 cells or Gas6-secreting NIH3T3 cells in N2 basal medium alone or N2 basal medium supplemented with $10 \mathrm{ng} / \mathrm{ml}$ PDGF, $5 \mathrm{ng} / \mathrm{ml}$ NT-3, or the combination of PDGF and NT-3. After $6 \mathrm{~d}$ in culture the cells were fixed and immunostained with antibody to CNPase. The number of primary and secondary processes as well as the length of the longest oligodendrocyte process was determined for three independent experiments $(n=150)$. $+++p<0.0001,++p=0.001,+p=0.002-0.01$ signifies a statistically significant difference between the Gas6-secreting cells and the control NIH3T3 cells; NS, not significant. $p$ values were obtained by unpaired two-tailed Student's $t$ test with $99 \%$ confidence.

Because low protein yields from isolated $\mathrm{O}^{+}$oligodendrocytes prevented us from examining the expression of the Axl receptor by immunoblotting, we performed double-label immunofluorescence of enriched oligodendrocyte cultures by using antibodies to $\mathrm{O} 4$ and Axl. Enriched oligodendrocyte cultures were grown on poly-lysine in the absence (minus Gas6) or the presence of $400 \mathrm{ng} / \mathrm{ml}$ recombinant human Gas6 (rhGas6; plus Gas6) in $\mathrm{N} 2$ basal medium containing PDGF and NT-3 and were fixed $6 \mathrm{~d}$ after plating. As shown in Figure $5 \mathrm{~A}, \mathrm{O} 4^{+}$oligodendrocytes grown in the presence of rhGas6 showed extensive process outgrowth and arborizations (red) as compared with the $\mathrm{O} 4{ }^{+}$oligodendrocytes grown in the absence of rhGas6 (Fig. 5D). Surviving oligodendrocytes grown in the absence of rhGas6 were not as numerous or as well branched as those receiving rhGas6 (compare Fig. $5 A, D)$. The $\mathrm{Axl}^{+}$oligodendrocytes in Figure $5 B$ and the $\mathrm{O}^{+} / \mathrm{Axl}^{+}$cells in Figure $4 C$ confirm that Axl is expressed on oligodendrocytes. As shown in Figure 5, $B$ and $C$, all of the $\mathrm{O}^{+}$ oligodendrocytes express the Axl receptor. At high magnification Axl receptor immunostaining appeared punctate (Fig. $5 \mathrm{H}$ ). Although an overwhelming majority of $\mathrm{O}^{+}$oligodendrocytes grown in the presence of rhGas6 for $6 \mathrm{~d}$ are $\mathrm{CNP}^{+}$, we were not able to perform colabeling of Axl with CNP because both antibodies are polyclonal antibodies. To verify that the Axl immunostaining in the $\mathrm{O}^{+} / \mathrm{Axl}^{+}$cells was not attributable to fluorescence associated with $\mathrm{O} 4$ staining, we performed single Axl staining on oligodendrocyte cultures grown in the presence of rhGas6. As shown in Figure 5J and the corresponding phasecontrast image in Figure $5 M$, all of the oligodendrocytes expressed the Axl receptor, and the staining was comparable to the $\mathrm{Axl} / \mathrm{O} 4$ double staining shown in Figure 5B. When the Axl antibody was preincubated with Axl-Fc (Fig. $5 K$ ) or the primary antibody was omitted (Fig. 5L), Axl immunostaining was not detected; corresponding phase images are presented in Figure 5, $N$ and $O$.

To determine whether rhGas6 initiated a proliferative response, we added BrdU to oligodendrocyte cultures. Doublelabel immunofluorescence with $\mathrm{O} 4$ and $\mathrm{BrdU}$ showed that in the absence of rhGas6 $15.2 \pm 2.2 \%$ of the cells were $\mathrm{O}^{+} / \mathrm{BrdU}^{+}$, whereas in the presence of rhGas6 $16.6 \pm 2.3 \%$ of the cells were double-labeled. This demonstrates that rhGas6 did not enhance the proliferation of $\mathrm{O}_{4}^{+}$oligodendrocytes. Because the BrdU studies ruled out a proliferative response for the role of Gas6, we examined whether rhGas 6 prolonged the survival of cultured oligodendrocytes. Untreated oligodendrocytes or oligodendrocytes treated with rhGas6 were fixed and incubated with either $\mathrm{O} 4$ or $\mathrm{CNP}$, followed by TUNEL labeling. $\mathrm{O}^{+} / \mathrm{TUNEL}^{+}$and $\mathrm{CNP}^{+} /$ $\mathrm{TUNEL}^{+}$double-labeled oligodendrocytes were counted in 25 independent fields from multiple wells. The addition of rhGas6 significantly reduced the number of TUNEL ${ }^{+}$oligodendrocytes. The proportion of $\mathrm{O}^{+}{ }^{+} \mathrm{TUNEL}^{+}$oligodendrocytes was reduced from $46.2 \pm 2.8$ to $22.9 \pm 2.5 \%$, whereas the $\mathrm{CNP}^{+} / \mathrm{TUNEL}^{+}$ oligodendrocytes were reduced from $52.3 \pm 3.3$ to $29.8 \pm 2.6 \%$ $(p<0.0001$ by two-tailed unpaired Student's $t$ test), suggesting that Gas6 served as a survival factor for oligodendrocytes. Representative low-magnification fields of $\mathrm{O}^{+} / \mathrm{TUNEL}^{+}$oligodendrocytes plated in the absence and presence of rhGas6 are shown in Figure 6, $A$ and $B$, respectively. As a consequence of prolonged survival of the oligodendrocyte, the cell extended more processes and arborizations.

A dose-response curve was performed with rhGas6 concentrations ranging between 25 and $400 \mathrm{ng} / \mathrm{ml}$ to determine the protective effect of rhGas6. Although the maximal survival effect of rhGas6 was observed at $400 \mathrm{ng} / \mathrm{ml}$ (Fig. 7), a protective effect was observed with rhGas 6 concentrations as low as $25 \mathrm{ng} / \mathrm{ml}$. The half-maximal value for the survival effect of rhGas6 was determined to be $100 \mathrm{ng} / \mathrm{ml}$. The survival effect was blocked by administering the rhGas6 with the Axl-Fc. To confirm further the specificity of the rhGas6 receptor interaction, we added 400 $\mathrm{ng} / \mathrm{ml} \mathrm{rhGas6}$ to cultures in the absence or presence of $10 \mu \mathrm{g} / \mathrm{ml}$ Axl-Fc or TrkA-Fc, the receptor for NGF. The total number of $\mathrm{CNP}^{+}$oligodendrocytes per well was counted. As shown in Figure 8 , there was a statistically significant increase in the overall number of $\mathrm{CNP}^{+}$cells in the presence of both rhGas6 (black) and rhGas6 plus TrkA-Fc (checkerboard) relative to the untreated cultures (white) or the rhGas6 plus Axl-Fc (stippled) cultures. In one experiment that was performed in triplicate wells, we examined the numbers of $\mathrm{CNP}^{+}$oligodendrocytes relative to the total number of attached cells per well (assessed by hematoxylin staining) after $6 \mathrm{~d}$ of treatment with or without rhGas6. In the untreated wells 432 of 2108 hematoxylin-stained cells were $\mathrm{CNP}^{+}$, whereas 806 of 1993 cells were $\mathrm{CNP}^{+}$in the rhGas6-treated wells. These data indicate that the rhGas6 promotes the survival of oligodendrocytes; the effect can be blocked by addition of the decoy-soluble Axl-Fc, but not the soluble TrkA-Fc.

In other systems the ligand activation of the Axl receptor has been shown to signal via either the MEK pathway or the Akt pathway. We next determined whether rhGas6 ligand activation stimulated signaling via the Akt pathway or the MEK pathway in fetal oligodendrocytes. To test this, we administered rhGas6 to the cultures in the presence and absence of Akt inhibitors LY294006 or wortmannin or the MEK inhibitor U0126. As shown in Figure 9, double-label immunofluorescence indicated that $19-22 \%$ of the cells grown in the presence of rhGas6 are $\mathrm{O}^{+}{ }^{+}$TUNEL $^{+}$(Fig. $9 A 1, B 1$, black bars) or $\mathrm{CNP}^{+} /$TUNEL $^{+}$ (Fig. 9A2,B2, black bars). A significant increase in the number of either $\mathrm{O}^{+} / \mathrm{TUNEL}^{+}$or $\mathrm{CNP}^{+} / \mathrm{TUNEL}^{+}$cells was observed when the oligodendrocytes were grown in the presence of rhGas6 and either LY294006 or wortmannin (checkerboard bars), demonstrating that blocking the Akt signaling pathway inhibits the effect of rhGas6. The MEK inhibitor had no effect on inhibiting the rhGas6 response (Fig. 10A1,A2). Note that results obtained with $\mathrm{CNP}^{+} / \mathrm{TUNEL}^{+}$oligodendrocytes were similar to those with $\mathrm{O}^{+} / \mathrm{TUNEL}^{+}$staining (Figs. 9A2,B2, 10A2) and again support a Gas6/Axl signaling pathway that signals downstream to Akt rather than the mitogenic MEK pathway. 

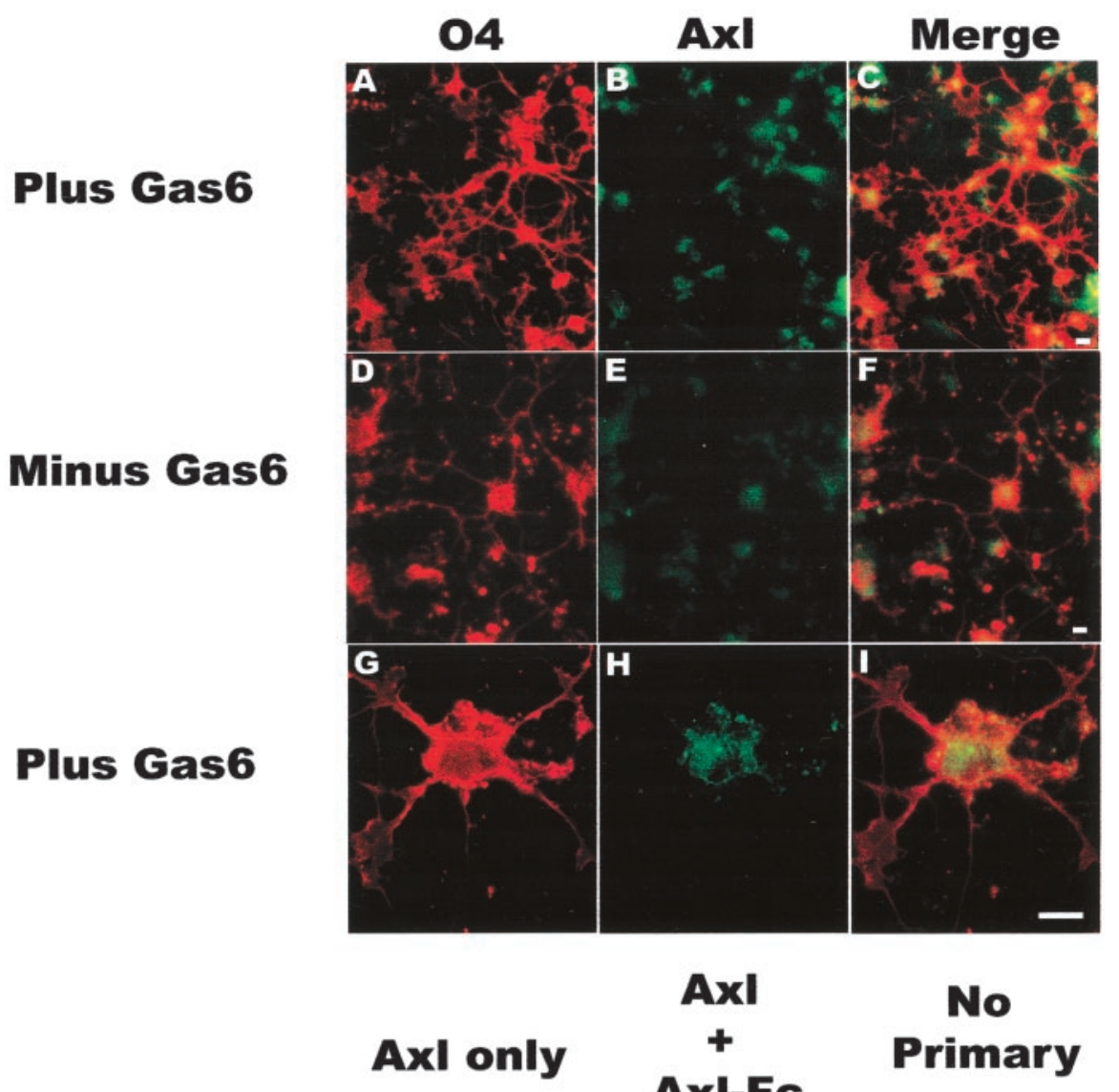

\section{Plus Gas6}

\section{Plus Gas6 Phase Contrast}
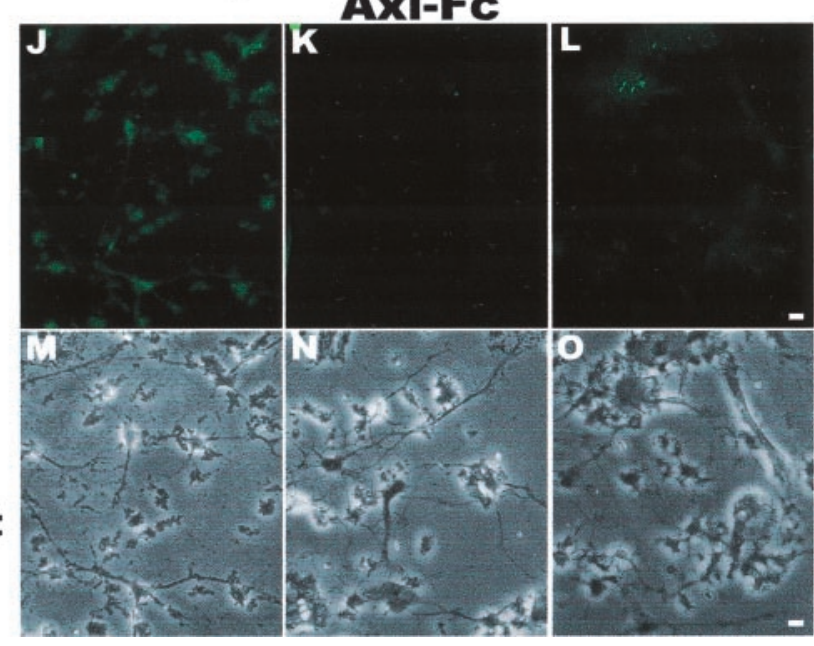

Figure 5. The Axl receptor is expressed on cultured oligodendrocytes. Cultures were grown in the absence (Minus Gas6) or the presence (Plus Gas6) of $400 \mathrm{ng} / \mathrm{ml}$ recombinant human Gas6 (rhGas6) in N2 basal medium containing PDGF and NT-3 and were fixed $6 \mathrm{~d}$ after plating. Oligodendrocytes were double-immunostained sequentially with Axl polyclonal antibody (green; $B, E, H$ ), followed by 04 monoclonal antibody (red; $A, D, G$ ). Red/green merged images are shown in $C, F, I$. A representative low-magnification field of oligodendrocytes with extensive process outgrowth and arborizations in the presence of rhGas 6 is shown in $A-C$. $G-l$ show a double-labeled oligodendrocyte with punctate Axl staining at high magnification. The $04{ }^{+} / \mathrm{Axl}^{+}$cells in $C, F$, I confirm that Axl is expressed on oligodendrocytes. J, M, Single staining of the Axl receptor on oligodendrocytes and the corresponding phase-contrast image in the presence of rhGas6. Preincubation of the Axl antibody with an $\mathrm{Axl}-\mathrm{Fc}(K, N)$ or omission of the primary antibody $(L, 0)$ eliminated the immunoreactivity and confirmed the specificity of Axl staining. Scale bars, $10 \mu \mathrm{m}$

\section{Discussion}

Our knowledge of oligodendrocyte biology for cells of human origin has been hampered by the poor availability of adult human CNS tissue and an inability to grow and maintain fetal human and primate oligodendrocytes in culture. Although human adult oligoden- drocytes can be maintained in culture (Kim, 1990), the conditions that support human adult oligodendrocytes do not support the survival of fetal human oligodendrocytes or oligodendrocytes isolated from macaques at any developmental stage, including the adult CNS [our laboratory and Dr. Baron-van Evercooren, Institut National de la Santé et de la Recherche Médicale (INSERM), Paris, France, personal communication]. Attempts to study oligodendrocyte biology by establishing neurospheres proved to be disappointing, because prolonged culturing gave rise to predominantly neurons with very few oligodendrocytes. The oligodendrocytes that were present resided within the astrocyte layer and incorporated BrdU; very few of the existing oligodendrocytes expressed mature oligodendrocyte markers (Zhang et al., 2000). These data suggest that additional trophic requirements, rather than the actual gestational age, are responsible for the inability to maintain fetal human and primate oligodendrocytes in culture.

In rodents the addition of individual growth factors or combinations thereof has identified specific factors that prolong the survival of cultured oligodendrocytes derived from optic nerve. Thus it has been shown that growth factors such as PDGF $\alpha$ decreased oligodendrocyte cell death and increased the number of oligodendrocytes in culture by twofold (Barres et al., 1992). Consistent with this finding we determined that PDGF $\alpha$ is important but is not sufficient for human oligodendrocyte survival in culture. Furthermore, the addition to our human fetal oligodendrocyte cultures of factors such as bFGF, neuregulin, or IGF-1 in combination with PDGF $\alpha$ did not enhance survival.

In an attempt to define additional growth factors involved in human oligodendrocyte growth and differentiation, we performed microarray analysis by using RNA isolated from $\mathrm{O}^{+}$fetal oligodendrocytes at 18 and $22 \mathrm{gw}$. In contrast to the brain, the spinal cord is myelinating rapidly at these time points, and thus all necessary growth and differentiation factors should be present in these samples. With the use of a stringent fourfold upregulation as cutoff, the results of these studies identified nine kinases that were expressed at high levels in these tissues, including both Axl and Mer, members of the Axl/ Mer/Rse receptor tyrosine kinase family. In humans Gas6 is the only known ligand for the Axl, Mer, and Rse receptors (Li et al., 1996), whereas in the mouse protein $S$ and Gas6 can activate the receptors (Stitt et al., 1995). Gas6 expression and secretion increase during growth arrest and bind to and activate the three receptors with different affinities. The Axl receptor is the most 


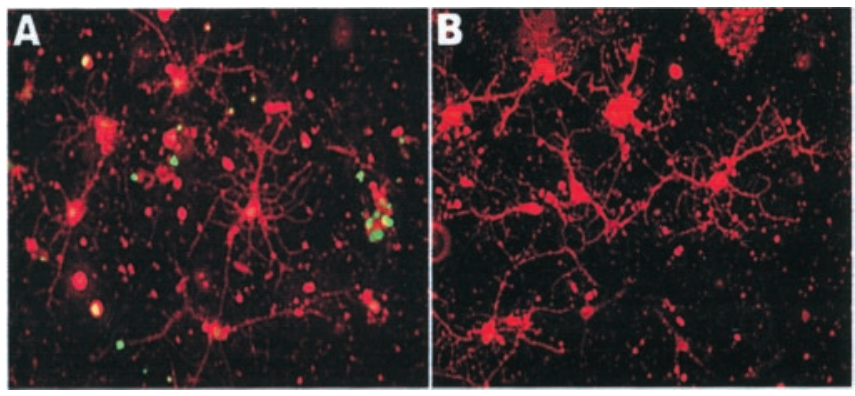

Figure 6. rhGas6 protects human oligodendrocytes from apoptosis. Oligodendrocytes were plated in the absence $(A)$ and presence $(B)$ of rhGas6 for $6 \mathrm{~d}$. Cells were fixed and immunostained with 04 (red), followed by TUNEL labeling (green). $04^{+} / \mathrm{TUNEL}^{+}$oligodendrocytes were observed in cultures grown in the absence of rhGas6 $(A)$.

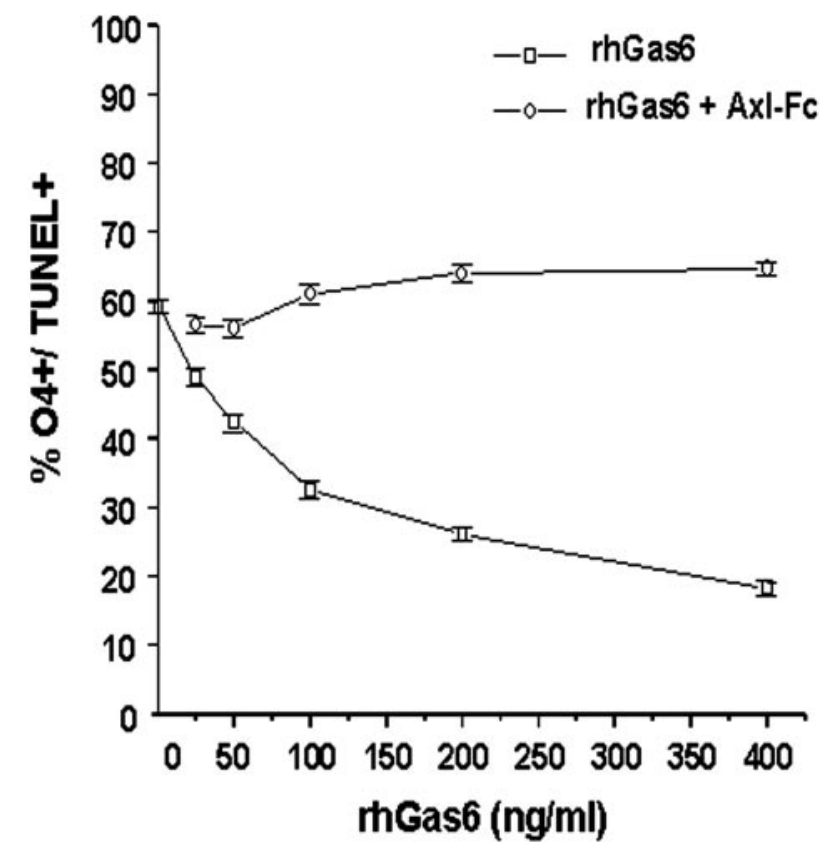

Figure 7. rhGas6/Axl signaling induces a dose-dependent reduction in human oligodendrocyte apoptosis. Oligodendrocytes were plated in N2 basal medium supplemented with PDGF and NT-3 on poly---lysine-coated plastic tissue culture wells in triplicate. Oligodendrocyte cultures were treated with varying concentrations of rhGas $6(25-400 \mathrm{ng} / \mathrm{ml})$ for $6 \mathrm{~d}$. Blocking experiments were performed with the said doses of rhGas 6 and $10 \mu \mathrm{g} / \mathrm{ml}$ Axl-Fc. Apoptotic oligodendrocytes were detected by immunofluorescence staining with the 04 antibody, followed by TUNEL staining. The numbers of $04^{+} / \mathrm{TUNEL}^{+}$double-labeled oligodendrocytes were counted from triplicate wells in 25 independent $20 \times$ microscopic fields and expressed as a percentage of the $04^{+}$cells per field. Data are shown as the mean \pm SEM of a representative experiment.

responsive to low doses of Gas6, whereas Mer requires higher doses of Gas6 for receptor activation (Godowski et al., 1995; Nagata et al., 1996).

Tyrosine kinases are important for cell survival, and in other cell types the Axl/Mer/Rse family of receptor tyrosine kinases protected against cell death in response to the removal of trophic support. In neurons Axl and Gas6 interact to protect from cell death in the absence of growth stimulation (Bellosta et al., 1997). Studies with sciatic nerve injury indicated an increase in Axl after damage, suggesting a role in survival and protection against apoptosis (Li et al., 1996). The anti-apoptotic effect of Axl signaling was confirmed by using fibroblasts from axl knock-out mice showing that the absence of Axl resulted in higher levels of serum deprivation-induced apoptosis, which could not be rescued by

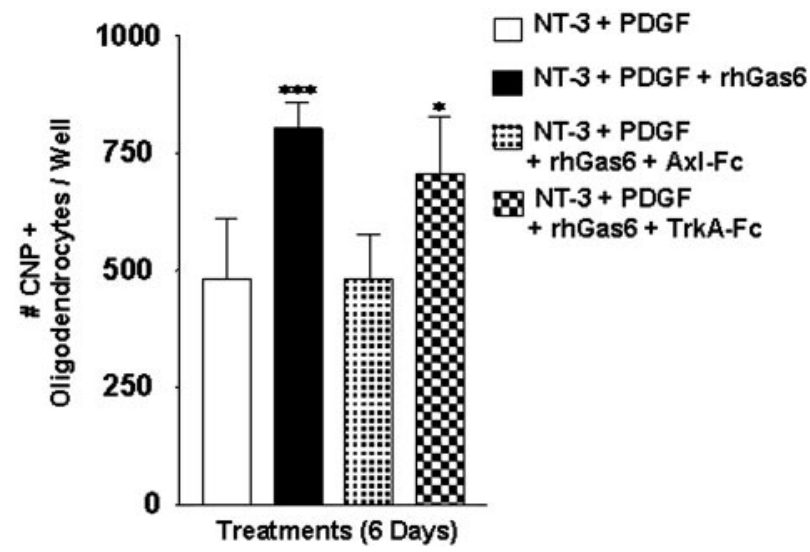

Figure 8. rhGas6 increases $\mathrm{CNP}^{+}$oligodendrocyte cell number when plated on poly-Llysine-coated wells. Oligodendrocyte cultures plated on poly--lysine-coated wells in N2 basal medium containing PDGF and NT-3 were treated with rhGas6 $(400 \mathrm{ng} / \mathrm{ml})$ in the absence or presence of $10 \mu \mathrm{g} / \mathrm{ml}$ Axl-Fc or TrkA-Fc for $6 \mathrm{~d}$. Oligodendrocytes were immunostained with a polyclonal CNP antibody. The total number of oligodendrocytes was counted from triplicate wells. Each error bar represents the mean $\pm \operatorname{SEM}(n=6)$ obtained from two independent experiments $\left({ }^{* * *} p=0.0002 ;{ }^{*} p=0.0124\right.$; unpaired Student's $t$ test).
A1.

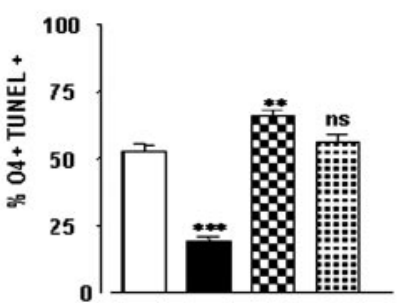

A2.

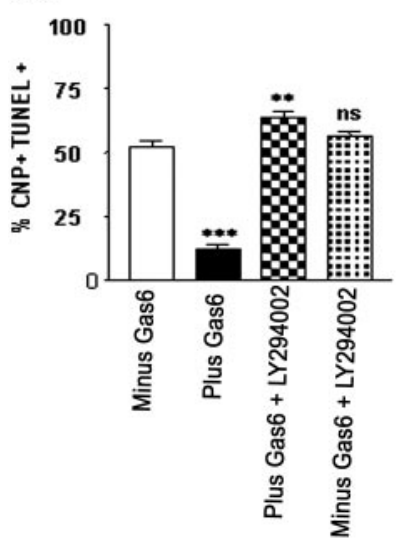

B1.

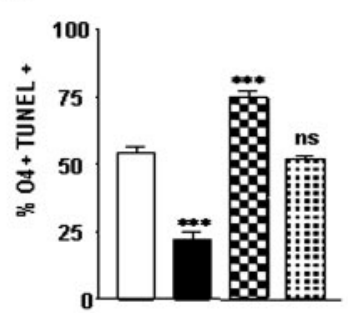

B2.

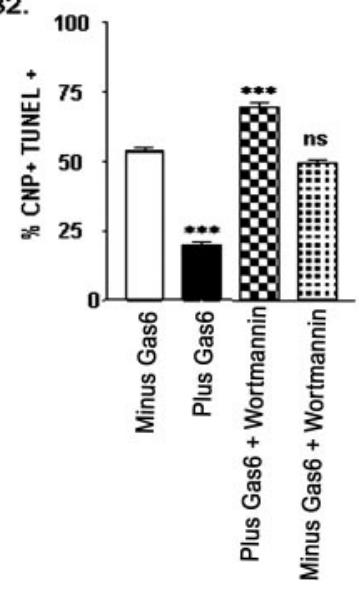

Figure 9. PI-3-kinase/Akt pathway inhibitors LY 294006 and wortmannin block rhGas6 signaling and increase the number of TUNEL ${ }^{+}$oligodendrocytes. For each experimental condition the oligodendrocytes were plated in N2 basal medium containing PDGF and NT-3 on poly-Llysine-coated plastic tissue culture wells in duplicate. rhGas6 $(400 \mathrm{ng} / \mathrm{ml})$ was administered to oligodendrocyte cultures for $6 \mathrm{~d}$ in the presence and absence of $10 \mathrm{~nm}$ LY 294006 or $100 \mathrm{~nm}$ wortmannin. The $04^{+} / \mathrm{TUNEL}^{+}$and $\mathrm{CNP}^{+} / \mathrm{TUNEL}^{+}$double-labeled oligodendrocyte cell numbers were counted from duplicate wells in 25 independent $20 \times$ microscopic fields and expressed as a percentage of the $04^{+}$or $\mathrm{CNP}^{+}$cells per field. Data are shown as the mean \pm SEM of a representative experiment $\left({ }^{* * *} p<0.0001\right.$; ${ }^{* *} p<0.01$; unpaired Student's t test; ns, not significant).

the addition of Gas6. Importantly, Axl signaling protected from apoptosis induced by serum deprivation, by myc overexpression, or by $\mathrm{TNF} \alpha$, but not from ultraviolet irradiation or staurosporine (Bellosta et al., 1997). These results suggest that a major function 
A1.

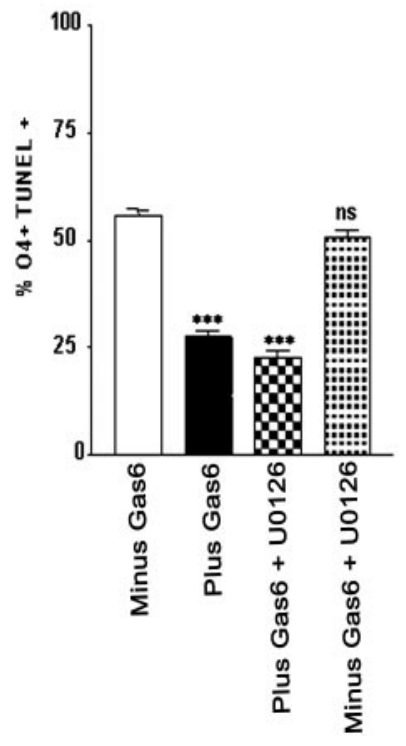

A2.

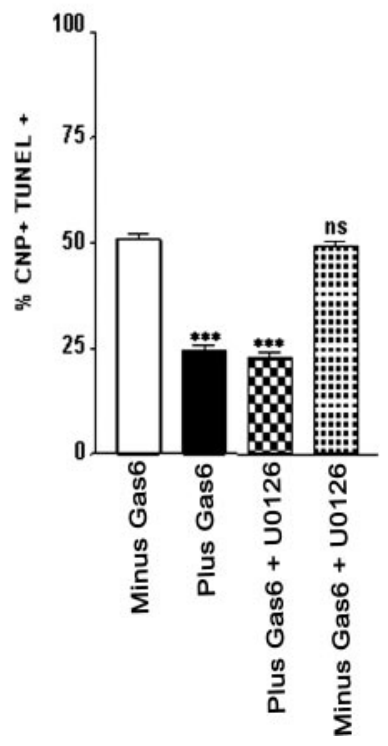

Figure 10. The ERK inhibitor U0126 does not inhibit the anti-apoptotic effect of rhGas6. rhGas6 $(400 \mathrm{ng} / \mathrm{ml})$ was administered to oligodendrocyte cultures on poly-L-lysine-coated plastic tissue culture wells in duplicate for $6 \mathrm{~d}$ in the presence and absence of the ERK inhibitor U0126 $(10 \mu \mathrm{m})$. The numbers of $04^{+} / \mathrm{TUNEL}^{+}$and $\mathrm{CNP}^{+} / \mathrm{TUNEL}^{+}$double-labeled oligodendrocytes were counted from duplicate wells in 25 independent $20 \times$ microscopic fields and expressed as a percentage of the $04^{+}$or CNP ${ }^{+}$cells per field. Data are shown as the mean \pm SEM of a representative experiment ( ${ }^{* * *} p<0.0001$; unpaired Student's $t$ test; ns, not significant).

of Gas6/Axl signaling is that of increasing cell survival under conditions that do not allow cell proliferation. Binding of ligand to the tyrosine receptor on the cell surface results in the activation of intrinsic tyrosine kinase activity (Jing et al., 1992) and activation of downstream signaling pathways. Depending on the cell type, Gas6 activation of the Axl/Mer/Rse receptors induced Src nonreceptor tyrosine kinase family members, phosphatidylinositol 3-kinase (PI3-kinase), Ras, and Erk2. Ras was shown to be required for the mitogenic response, but not the survival response (Takano et al., 2000). The survival response has been shown to be mediated via the Akt pathway (Ding et al., 2000; Takano et al., 2000). Thus the expression of Gas6 in spinal motor neurons, dorsal root ganglion neurons, and in developing embryos supports a role for Gas6/Axl in nervous system development and repair after spinal cord injury (Li et al., 1996).

Because Gas6 has been implicated in growth and survival activity in other cell types, we explored the possibility that Gas6 also could function in this regard for fetal human oligodendrocytes. Staining of fetal spinal cord with an antibody to Axl confirmed its expression on oligodendrocytes in white matter at 21 gw. In vitro, enriched cultures of oligodendrocytes also expressed Axl. Human fetal oligodendrocytes plated on poly-L-lysine were moderately viable in N2 basal medium supplemented with PDGF and NT-3; however, the addition of rhGas6 $(400 \mathrm{ng} / \mathrm{ml})$ administered in this medium enhanced human fetal oligodendrocyte survival twofold and dramatically decreased the number of $\mathrm{O}^{+} / \mathrm{TUNEL}^{+}$oligodendrocytes from $\sim 60$ to $18 \%$ (Fig. 7). A statistically significant increase in the total number of $\mathrm{O}^{+}{ }^{+}$or $\mathrm{CNP}^{+}$cells relative to untreated cultures was observed in oligodendrocyte cultures treated with rhGas6. The effect of rhGas6 was blocked with a decoy-soluble Axl-Fc, but not by TrkA-Fc (Fig. 8). Oligodendrocyte survival was not accompanied by BrdU incorporation, indicating that the response was not a result of cell proliferation.

From these data we conclude that Gas6 functions as a survival factor that supports the viability of human fetal oligodendrocytes.

Although we have not defined the specific receptor involved in this response, a role for Axl can be inferred from these results. This is based on the observation that protection from cell death occurred with as little as $25 \mathrm{ng} / \mathrm{ml}$ rhGas 6 and that the survival response was blocked by the Axl-Fc region of the receptor. We were unable to determine the specific receptor tyrosine kinases activated by Gas6, because the amount of protein obtained from the cultured fetal oligodendrocytes was limiting and was insufficient to perform ELISA-based kinase receptor activation assays or immunoprecipitations (Godowski et al., 1995; Varnum et al., 1995; Goruppi et al., 1997). Regardless of the specific tyrosine kinase receptor that was used, rhGas6-treated oligodendrocytes were protected from apoptosis and appeared healthier with more primary processes and arborizations than the untreated oligodendrocyte cultures. One might speculate, therefore, that in vivo the secretion of Gas6 by growth-arrested, differentiated neurons activates oligodendrocyte signaling pathways that result in enhanced oligodendrocyte cell survival, process outgrowth, and perhaps neuron/oligodendrocyte interactions. In future studies we will examine the Gas6 activation of the receptor(s) in cultured oligodendrocytes from the single and double knock-outs of Axl and Rse mice. Mer knock-out mice fail to clear apoptotic cells; thus it is concluded that activation of the functional Mer receptor is required for phagocytosis and clearance of apoptotic cells (Scott et al., 2001).

The G domains of Gas6 functionally interact with the Axl/Rse/ Mer receptors and activate signaling pathways (Mark et al., 1996). In the oligodendrocyte cultures the Gas6 protective response was obliterated by inhibition of the PI3-kinase/Akt pathway, but not by an inhibitor of the MEK/ERK signaling cascade. This supports our hypothesis that Gas6 is a survival factor for oligodendrocytes and does not function in cell cycle progression. These results are consistent with the differentiated phenotype of the oligodendrocytes at the examined developmental stages (18-23 gw), a period when active myelination is ongoing in fetal spinal cord. Our findings implicate Gas6 as a novel and hitherto unrecognized survival factor for human oligodendrocytes.

\section{References}

Albala JS, Kress Y, Liu WK, Weidenheim K, Yen SH, Shafit-Zagardo B (1995) Human microtubule-associated protein-2c localizes to dendrites and axons in fetal spinal motor neurons. J Neurochem 64:2480-2490.

Bansal R, Warrington AE, Gard AL, Ranscht B, Pfeiffer SE (1989) Multiple and novel specificities of monoclonal antibodies $\mathrm{O} 1, \mathrm{O} 4$, and R-mAb used in the analysis of oligodendrocyte development. J Neurosci Res 24:548-557.

Barres BA, Hart IK, Coles HS, Burne JF, Voyvodic JT, Richardson WD, Raff MC (1992) Cell death and control of cell survival in the oligodendrocyte lineage. Cell 70:31-46.

Bellosta P, Zhang Q, Goff SP, Basilico C (1997) Signaling through the ARK tyrosine kinase receptor protects from apoptosis in the absence of growth stimulation. Oncogene 15:2387-2397.

Bodhireddy SR, Lyman WD, Rashbaum WK, Weidenheim KM (1994) Immunohistochemical detection of myelin basic protein is a sensitive marker of myelination in second trimester human fetal spinal cord. J Neuropathol Exp Neurol 53:144-149.

Dai W, Pan H, Hassanain H, Gupta SL, Murphy Jr MJ (1994) Molecular cloning of a novel receptor tyrosine kinase, tif, highly expressed in human ovary and testis. Oncogene 9:975-979.

Ding J, Takano T, Gao S, Han W, Noda C, Yanagi S, Yamamura H (2000) Syk is required for the activation of Akt survival pathway in B cells exposed to oxidative stress. J Biol Chem 275:30873-30877.

Dormady SP, Zhang XM, Basch RS (2000) Hematopoietic progenitor cells grow on 3T3 fibroblast monolayers that overexpress growth arrest-specific gene-6. Proc Natl Acad Sci USA 97:12260-12265. 
Faust M, Ebensperger C, Schulz AS, Schleithoff L, Hameister H, Bartram CR, Janssen JW (1992) The murine ufo receptor: molecular cloning, chromosomal localization, and in situ expression analysis. Oncogene 7:1287-1293.

Fujimoto J, Yamamoto T (1994) brt, a mouse gene encoding a novel receptor-type protein-tyrosine kinase, is preferentially expressed in the brain. Oncogene 9:693-698.

Funakoshi H, Yonemasu T, Nakano T, Matumoto K, Nakamura T (2002) Identification of Gas6, a putative ligand for Sky and Axl receptor tyrosine kinases, as a novel neurotrophic factor for hippocampal neurons. J Neurosci Res 68:150-160.

Gard AL, Pfeiffer SE (1989) Oligodendrocyte progenitors isolated directly from developing telencephalon at a specific phenotypic stage: myelinogenic potential in a defined environment. Development 106:119-132.

Gard AL, Warrington AE, Pfeiffer SE (1988) Direct microculture enzymelinked immunosorbent assay for studying neural cells: oligodendrocytes. J Neurosci Res 20:46-53.

Godowski PJ, Mark MR, Chen J, Sadick MD, Raab H, Hammonds RG (1995) Reevaluation of the roles of protein $\mathrm{S}$ and Gas6 as ligands for the receptor tyrosine kinase Rse/Tyro 3. Cell 82:355-358.

Goruppi S, Ruaro E, Schneider C (1996) Gas6, the ligand of Axl tyrosine kinase receptor, has mitogenic and survival activities for serum-starved NIH3T3 fibroblasts. Oncogene 12:471-480.

Goruppi S, Ruaro E, Varnum B, Schneider C (1997) Requirement of phosphatidylinositol 3-kinase-dependent pathway and Src for Gas6-Axl mitogenic and survival activities in NIH 3T3 fibroblasts. Mol Cell Biol 17:4442-4453.

Graham DK, Dawson TL, Mullaney DL, Snodgrass HR, Earp HS (1994) Cloning and mRNA expression analysis of a novel human protooncogene, c-mer. Cell Growth Differ 5:647-657.

Healy AM, Schwartz JJ, Zhu X, Herrick BE, Varnum B, Farber HW (2001) Gas6 promotes Axl-mediated survival in pulmonary endothelial cells. Am J Physiol Lung Cell Mol Physiol 280:L1273-L1281.

Hern WM (1984) Correlation of fetal age and measurements between 10 and 26 weeks of gestation. Obstet Gynecol 63:26-32.

Janssen JW, Schulz AS, Steenvoorden AC, Schmidberger M, Strehl S, Ambros PF, Bartram CR (1991) A novel putative tyrosine kinase receptor with oncogenic potential. Oncogene 6:2113-2120.

Jia R, Hanafusa H (1994) The proto-oncogene of $v$-eyk $(v-r y k)$ is a novel receptor-type protein tyrosine kinase with extracellular Ig/GN-III domains. J Biol Chem 269:1839-1844.

Jia R, Mayer BJ, Hanafusa T, Hanafusa H (1992) A novel oncogene, v-ryk, encoding a truncated receptor tyrosine kinase is transduced into the RPL30 virus without loss of viral sequences. J Virol 66:5975-5987.

Jing S, Tapley P, Barbacid M (1992) Nerve growth factor mediates signal transduction through Trk homodimer receptors. Neuron 9:1067-1079.

Kashima T, Tiu SN, Merrill JE, Vinters HV, Dawson G, Campagnoni AT (1993) Expression of oligodendrocyte-associated genes in cell lines derived from human gliomas and neuroblastomas. Cancer Res 53:170-175.

Kim SU (1990) Neurobiology of human oligodendrocytes in culture. J Neurosci Res 27:712-728.

Laemmli UK (1970) Cleavage of structural proteins during the assembly of the head of the bacteriophage T4. Nature 227:680-685.

Lai C, Lemke G (1991) An extended family of protein-tyrosine kinase genes differentially expressed in the vertebrate nervous system. Neuron 6:691-704.

Lai C, Gore M, Lemke G (1994) Structure, expression, and activity of Tyro 3, a neural adhesion-related receptor tyrosine kinase. Oncogene 9:2567-2578.

Li R, Chen J, Hammonds G, Phillips H, Armanini M, Wood P, Bunge R, Godowski PJ, Sliwkowski MX, Mather JP (1996) Identification of Gas6 as a growth factor for human Schwann cells. J Neurosci 16:2012-2019.

Ling L, Kung HJ (1995) Mitogenic signals and transforming potential of Nyk, a newly identified neural cell adhesion molecule-related receptor tyrosine kinase. Mol Cell Biol 15:6582-6592.

Mark MR, Chen J, Hammonds RG, Sadick M, Godowski PJ (1996) Characterization of Gas6, a member of the superfamily of G domain-containing proteins, as a ligand for Rse and Axl. J Biol Chem 271:9785-9789.

McCloskey P, Fridell YW, Attar E, Villa J, Jin Y, Varnum B, Liu ET (1997)
Gas6 mediates adhesion of cells expressing the receptor tyrosine kinase Axl. J Biol Chem 272:23285-23291.

Nagata K, Ohashi K, Nakano T, Arita H, Zong C, Hanafusa H, Mizuno K (1996) Identification of the product of growth arrest-specific gene 6 as a common ligand for Axl, Sky, and Mer receptor tyrosine kinases. J Biol Chem 271:30022-30027.

O’Bryan JP, Frye RA, Cogswell PC, Neubauer A, Kitch B, Prokop C, Espinosa 3rd R, Le Beau MM, Earp HS, Liu ET (1991) axl, a transforming gene isolated from primary human myeloid leukemia cells, encodes a novel receptor tyrosine kinase. Mol Cell Biol 11:5016-5031.

O’Donnell K, Harkes IC, Dougherty L, Wicks IP (1999) Expression of receptor tyrosine kinase Axl and its ligand Gas6 in rheumatoid arthritis: evidence for a novel endothelial cell survival pathway. Am J Pathol 154:1171-1180.

Ohashi K, Mizuno K, Kuma K, Miyata T, Nakamura T (1994) Cloning of the cDNA for a novel receptor tyrosine kinase, Sky, predominantly expressed in brain. Oncogene 9:699-705.

Pfeiffer SE, Warrington AE, Bansal R (1993) The oligodendrocyte and its many cellular processes. Trends Neurosci 3:191-197.

Prieto A, Weber JL, Lai C (2000) Expression of the receptor protein tyrosine kinase Tyro3, Axl, and Mer in the developing rat central nervous system. J Comp Neurol 425:295-314.

Raff MC, Miller RH, Noble M (1983) A glial progenitor cell that develops in vitro into an astrocyte or an oligodendrocyte depending on culture medium. Nature 303:390-396.

Raible DW, McMorris FA (1989) Cyclic AMP regulates the rate of differentiation of oligodendrocytes without changing the lineage commitment of their progenitors. Dev Biol 133:437-446.

Rescigno J, Mansukhani A, Basilico C (1991) A putative receptor tyrosine kinase with unique structural topology. Oncogene 6:1909-1913.

Scott RS, McMahon EJ, Pop SM, Reap EA, Caricchio R, Cohen PL, Earp HS, Matsushima GK (2001) Phagocytosis and clearance of apoptotic cells is mediated by MER. Nature 411:207-211.

Shafit-Zagardo B, Kress Y, Zhao ML, Lee SC (1999) Reexpression of a novel, oligodendrocyte-specific MAP-2 isoform in multiple sclerosis lesions. J Neurochem 73:2531-2537.

Shafit-Zagardo B, Davies P, Rockwood J, Kress Y, Lee SC (2000) A novel MAP-2 isoform expressed early in human oligodendrocyte maturation. Glia 29:233-245.

Sommer I, Schachner M (1981) Monoclonal antibodies (O1 to O4) to oligodendrocyte cell surfaces: an immunocytological study in the central nervous system. Dev Biol 83:311-327.

Stitt TN, Conn G, Gore M, Lai C, Bruno J, Radziejewski C, Mattsson K, Fisher J, Gies DR, Jones PF, Masiakowski P, Ryan TE, Tobkes NJ, Chen DH, DiStefano PS, Long GL, Basilico C, Goldfarb MP, Lemke G, Glass DJ, Yancopoulos GD (1995) The anticoagulation factor protein S and its relative, Gas6, are ligands for the Tyro 3/Axl family of receptor tyrosine kinases. Cell 80:661-670.

Streeter GL (1920) Weight, sitting height, head size, foot length, and menstrual age of the human embryo. Contrib Embryol 55:143-170.

Takano R, Hisahara S, Namikawa K, Kiyama, Okano H, Miura M (2000) NGF protects oligodendrocytes from TNF- $\alpha$-induced injury through Akt-mediated signaling mechanisms. J Biol Chem 275:16360-16365.

Towbin H, Staehelin T, Gordon J (1979) Electrophoretic transfer of proteins from polyacrylamide gels to nitrocellulose sheets: procedure and some applications. Proc Natl Acad Sci USA 76:4350-4354.

Trapp BD, Nishiyama A, Cheng D, Macklin W (1997) Differentiation and death of premyelinating oligodendrocytes in developing rodent brain. J Cell Biol 137:459-468.

Varnum BC, Young C, Elliott G, Garcia A, Bartley TD, Fridell YW, Hunt RW, Trail G, Clogston C, Toso RJ, Yanagihara D, Bennett L, Sylber M, Merewether LA, Tseng A, Escobar E, Liu ET, Yamane HK (1995) Axl receptor tyrosine kinase stimulated by the vitamin K-dependent protein encoded by growth arrest-specific gene 6. Nature 373:623-626.

Weidenheim KM, Bodhireddy SR, Rashbaum WK, Lyman WD (1996) Temporal and spatial expression of major myelin proteins in the human fetal spinal cord during the second trimester. J Neuropathol Exp Neurol 55:734-745.

Zhang SC, Ge B, Duncan ID (2000) Tracing human oligodendroglial development in vitro. J Neurosci Res 59:421-429. 